\title{
Fault damage zone volume and initial salinity distribution determine intensity of shallow aquifer salinisation in subsurface storage
}

\author{
Elena Tillner $^{1}$, Maria Langer ${ }^{1}$, Thomas Kempka ${ }^{1}$, and Michael Kühn ${ }^{1,2}$ \\ ${ }^{1}$ GFZ German Research Centre for Geosciences, Telegrafenberg, 14473 Potsdam, Germany \\ ${ }^{2}$ University of Potsdam, Institute of Earth- and Environmental Science, Karl-Liebknecht-Str. 24/25, 14476 Potsdam, Germany \\ Correspondence to: Elena Tillner (elena.tillner@gfz-potsdam.de)
}

Received: 21 April 2015 - Published in Hydrol. Earth Syst. Sci. Discuss.: 16 June 2015

Revised: 2 December 2015 - Accepted: 11 February 2016 - Published: 8 March 2016

\begin{abstract}
Injection of fluids into deep saline aquifers causes a pore pressure increase in the storage formation, and thus displacement of resident brine. Via hydraulically conductive faults, brine may migrate upwards into shallower aquifers and lead to unwanted salinisation of potable groundwater resources. In the present study, we investigated different scenarios for a potential storage site in the Northeast German Basin using a three-dimensional (3-D) regional-scale model that includes four major fault zones. The focus was on assessing the impact of fault length and the effect of a secondary reservoir above the storage formation, as well as model boundary conditions and initial salinity distribution on the potential salinisation of shallow groundwater resources. We employed numerical simulations of brine injection as a representative fluid.

Our simulation results demonstrate that the lateral model boundary settings and the effective fault damage zone volume have the greatest influence on pressure build-up and development within the reservoir, and thus intensity and duration of fluid flow through the faults. Higher vertical pressure gradients for short fault segments or a small effective fault damage zone volume result in the highest salinisation potential due to a larger vertical fault height affected by fluid displacement. Consequently, it has a strong impact on the degree of shallow aquifer salinisation, whether a gradient in salinity exists or the saltwater-freshwater interface lies below the fluid displacement depth in the faults. A small effective fault damage zone volume or low fault permeability further extend the duration of fluid flow, which can persist for several tens to hundreds of years, if the reservoir is laterally confined. Laterally open reservoir boundaries, large effective fault damage zone volumes and intermediate reservoirs significantly
\end{abstract}

reduce vertical brine migration and the potential of freshwater salinisation because the origin depth of displaced brine is located only a few decametres below the shallow aquifer in maximum.

The present study demonstrates that the existence of hydraulically conductive faults is not necessarily an exclusion criterion for potential injection sites, because salinisation of shallower aquifers strongly depends on initial salinity distribution, location of hydraulically conductive faults and their effective damage zone volumes as well as geological boundary conditions.

\section{Introduction}

Carbon Capture and Storage (CCS) can contribute to the reduction of global anthropogenic carbon dioxide emissions. Different geological underground formations have been suggested as target storage sites, such as deep saltwater-bearing aquifers (saline aquifers) providing the worldwide largest storage potential as part of the Earth's widely distributed sedimentary basins (IPCC, 2005). Shallow aquifers in sedimentary basins can comprise considerable freshwater resources, which in turn are generally of great importance for regional water supplies. However, brine displacement due to the elevated pore pressure in the storage formation is one potential risk of $\mathrm{CO}_{2}$ storage in deep saline aquifers. Saline fluids could reach shallower freshwater aquifers through different migration pathways, and significantly impair groundwater quality. Fault zones are of particular importance, as they might transect several cap rocks, and thus can provide large-scale permeable conduits between aquifers at different 
depths (Dempsey et al., 2014; Fitts and Peters, 2013; Chiaramonte et al., 2008; IEAGHG, 2008; Bense and Person, 2006; Forster and Evans, 1991).

Displacement of brine and potential freshwater salinisation as a result of $\mathrm{CO}_{2}$ storage has been investigated in several studies. Table 1 summarises the initial conditions and essential results of numerical simulations concerning this issue. The models applied are either synthetic (Birkholzer et al., 2009, 2011; Oldenburg and Rinaldi, 2011) or refer to a certain study area (Tillner et al., 2013a; Zouh et al., 2010; Yamamoto et al., 2009; Nicot, 2008). Several studies examine pressure perturbation and resulting brine migration in a multi-barrier system without considering vertical conduits. It was shown that pressure build-up can be observed at a distance of more than $100 \mathrm{~km}$ from the injection zone (Birkholzer et al., 2009). The choice of boundary conditions and petrophysical parameters have a crucial impact on the pressure propagation, as demonstrated by two independent studies considering industrial-scale $\mathrm{CO}_{2}$ injection in the Illinois Basin (Person et al., 2010; Zhou et al., 2010). According to Person et al. (2010), the pressure perturbation is limited to a distance of about $25 \mathrm{~km}$ from the injection location for a total injection rate of $80 \mathrm{MtCO}_{2}$ year $^{-1}$, whereas Zhou et al. (2010) simulated a pressure build-up as far as $300 \mathrm{~km}$ from the injection area $\left(100 \mathrm{MtCO}_{2}\right.$ year $\left.^{-1}\right)$. The disparity between the simulation results is mainly related to the fact that Person et al. (2010) assumed considerably lower reservoir formation permeability, higher formation compressibility and closed lateral flow boundaries except for the northern model domain, whereas Zhou et al. (2010) applied laterally open flow boundaries (Table 1).

However, upward brine migration only occurs if pressure perturbation in the reservoir is large enough to overcome the weight of the fluid column in a vertical conduit. Whether a steady state is reached or continuous flow develops further depends on the magnitude of pressure increase, and whether brine is allowed to spread unhindered in the upper aquifer due to a continuous hydraulic connection throughout the formation without barriers to flow (Birkholzer et al., 2011; Oldenburg and Rinaldi, 2011). As stated previously, faults, in particular, can represent vertical conduits, which may have an essential influence on groundwater flow and brine migration due to their extent and distribution in the Earth's upper crust. Nevertheless, a meaningful implementation of complex geological structures into a sufficiently discretised model grid is difficult, especially at a regional scale. Tillner et al. (2013a) investigated the influence of permeable faults on brine displacement referring to a real study area. The authors simulated upward brine migration through complex fault systems depending on reservoir compartmentalisation and fault permeability, whereby faults were implemented by the virtual element approach (Nakaten et al., 2013). The results of Tillner et al. (2013a) showed that the degree of pressurisation is the driving mechanism for brine migration, while an increase of fault per- meability from $100 \mathrm{mD}$ by 2 orders of magnitude had no significant impact on the salinisation of shallower aquifers. Their investigations focused on the prospective storage site Beeskow-Birkholz (in the following only referred to as Beeskow) in northeast Germany, which is also considered in this work.

Here, we present a regional-scale 3-D model with a simplified geometry, neglecting topographic variations of the formation tops and bases, while the four considered fault zones are implemented with their complex arrangement and curvature to focus the analysis on clearly identifiable effects of fault fluid flow. The presumed simplifications further significantly improved the convergence efficiency of the simulations and avoided numerical artefacts. In different leakage scenarios the impact of fault lengths, hydrogeological boundary conditions, initial salinity distribution and the presence of an overlying secondary reservoir on upward brine displacement were assessed to deepen our understanding on potential freshwater salinisation resulting from fluid injection into deep saline formations.

\section{Study area}

The potential $\mathrm{CO}_{2}$ storage site is located close to the town Beeskow in the Northeast German Basin (NEGB; Fig. 1a). In a respective industrial project and according to the estimated storage capacity, it was planned to inject $34 \mathrm{MtCO}_{2}$ over a period of 20 years $\left(1.7 \mathrm{MtCO}_{2}\right.$ year $\left.^{-1}\right)$ into the basal sandstones of the Detfurth Formation from the Middle Buntsandstein (Lower Triassic); (Vattenfall, 2009, 2010). Porous and fractured sediments of the Lower Muschelkalk (Middle Triassic) represent a secondary suitable reservoir above the target storage horizon (Fig. 2a). A multi-barrier system of different cap rocks, mainly anhydrites, halites and claystones from the Upper Buntsandstein, the Middle and Upper Muschelkalk, as well as the Lower Keuper seals the Detfurth Formation and the overlying secondary reservoirs. The basal sandstones of the Rupelian (Oligocene, Upper Tertiary) at a depth between 100 and $150 \mathrm{~m}$ in average mark the beginning of saltwater-bearing aquifers in the area (Kempka et al., 2015a; Grube et al., 2000; Hannemann and Schirrmeister, 1998; Stackebrandt, 1998).

The fault system of the study area consists of four regional fault zones comprising several individual faults. It divides the sedimentary cover of the study area into a regional block structure (Mittenwalde Block; Fig. 1b). The Lausitzer Abbruch and the Fuerstenwalde-Guben fault zones with northwest to south-east (NW-SE) orientation, as well as the Tauer and the Potsdam fault zones striking NE-SW, enclose this compartment. All faults are normal faults with a steep inclination (between 67.8 and $74.3^{\circ}$ in average) and an offset between a few hundred metres and $1000 \mathrm{~m}$ (Hotzan and Voss, 2013; Beutler and Stackebrandt, 2012; Stackebrandt and Manhenke, 2004). 
Table 1. Summary of numerical simulations of brine migration resulting from $\mathrm{CO}_{2}$ injection.

\begin{tabular}{|c|c|c|c|c|c|c|}
\hline Authors & $\begin{array}{l}\text { Study area and model } \\
\text { extend }\end{array}$ & $\begin{array}{l}\text { Reservoir } \\
\text { boundaries }\end{array}$ & Simulator & $\begin{array}{l}\text { Injection and } \\
\text { duration }\end{array}$ & $\begin{array}{l}\text { Injected } \\
\text { fluid }\end{array}$ & Objectives \\
\hline $\begin{array}{l}\text { Birkholzer et al. } \\
(2009)\end{array}$ & $\begin{array}{l}\text { - synthetic } \\
-125000 \mathrm{~km}^{2} \\
\text { (radial symmetric) }\end{array}$ & open & $\begin{array}{l}\text { TOUGH2/ } \\
\text { ECO2N }\end{array}$ & $\begin{array}{l}1.52 \mathrm{Mt} \mathrm{yr}^{-1} \\
\text { over } 30 \text { years }\end{array}$ & $\mathrm{CO}_{2}$ & $\begin{array}{l}\text { Pressure build-up } \\
\text { and brine migration } \\
\text { in the reservoir and } \\
\text { through low perme- } \\
\text { able cap rocks }\end{array}$ \\
\hline $\begin{array}{l}\text { Birkholzer et al. } \\
\text { (2011) }\end{array}$ & $\begin{array}{l}\text { - synthetic } \\
-12 \mathrm{~km}^{2} \\
\text { (radial symmetric) }\end{array}$ & closed & $\begin{array}{l}\text { TOUGH2/ } \\
\text { EOS7 }\end{array}$ & $\begin{array}{l}\text { Simulated by } \\
\text { pressure } \\
\text { build-up }\end{array}$ & - & $\begin{array}{l}\text { Brine migration up a } \\
\text { leaking wellbore. }\end{array}$ \\
\hline
\end{tabular}

\begin{tabular}{llllll}
\hline Nicot (2008) & $\begin{array}{l}\text { - Gulf Coast, USA } \\
-80000 \mathrm{~km}^{2}\end{array}$ & closed & MODLFLOW96 & $\begin{array}{l}50 \text { and } \\
250 \mathrm{Mt} \mathrm{yr}^{-1} \\
\text { over 50 years }\end{array}$ & Water \\
& & & & \\
& & & & \\
\hline $\begin{array}{l}\text { Oldenburg and } \\
\text { Rinaldi (2011) }\end{array}$ & -1 synthetic & closed & TOUGH2/ & $\begin{array}{l}\text { Simulated } \\
\text { by pressure } \\
\text { build-up }\end{array}$ \\
\end{tabular}

Pressure build-up and brine migration in the reservoir and through low permeable cap rocks. Results Brine displacement in shallower aquifers through a vertical conduit (borehole or fault).

- Considerable pressure buildup at a distance of $>100 \mathrm{~km}$ from injection zone. - Vertical brine migration through a sequence of seals extremely unlikely.

- Continuous flow only occurs if pressure perturbation in the reservoir is large enough to overcome the increased weight of the fluid column

- Average water table rise is in the same order of magnitude as seasonal and inter-annual variations.

- Depending on brine density and pressure gradient fluid migrates upward until a new static steady-state equilibrium is reached or a sustained flow develops, if the brine is allowed to spread laterally.

\begin{tabular}{|c|c|c|c|c|}
\hline $\begin{array}{l}\text { Person et al. } \\
(2010)\end{array}$ & $\begin{array}{l}\text { - Illinois Basin, USA } \\
-3000-241000 \mathrm{~km}^{2}\end{array}$ & $\begin{array}{l}\text { closed and } \\
\text { open }\end{array}$ & $\begin{array}{l}\text { Analytical } \\
\text { single-phase and } \\
\text { sharp-interface } \\
\text { models }\end{array}$ & $\begin{array}{l}80 \mathrm{Mt} \mathrm{yr}^{-1} \\
\text { over } \\
100 \text { years }\end{array}$ \\
\hline
\end{tabular}

\begin{tabular}{|c|c|c|c|c|c|c|}
\hline $\begin{array}{l}\text { Tillner et al. } \\
\text { (2013a) }\end{array}$ & $\begin{array}{l}\text { - North German Basin } \\
-1764 \mathrm{~km}^{2}\end{array}$ & $\begin{array}{l}\text { closed and } \\
\text { open }\end{array}$ & $\begin{array}{l}\text { TOUGH2-MP/ } \\
\text { ECO2N }\end{array}$ & $\begin{array}{l}1.7 \mathrm{Mt} \mathrm{yr}^{-1} \\
\text { over } 20 \text { years }\end{array}$ & $\mathrm{CO}_{2}$ & $\begin{array}{l}\text { Brine migration } \\
\text { through faults depen- } \\
\text { dent on reservoir com- } \\
\text { partmentalisation and } \\
\text { fault permeability. }\end{array}$ \\
\hline
\end{tabular}

- No significant lateral brine migration due to distributed injection and vertical brine leakage across the confining unit.

- Pressure propagation (>0.3 bar) up to a distance of $10-25 \mathrm{~km}$ away from the injection wells.

- Degree of pressurisation is the driving mechanism for brine migration.

- Permeability of fault zones does not influence salinisation of shallower aquifers significantly.

\begin{tabular}{|c|c|c|c|c|c|c|c|}
\hline $\begin{array}{l}\text { Yamamoto et al. } \\
\text { (2009) }\end{array}$ & $\begin{array}{l}\text { - Bay of Tokyo, Japan } \\
-4200 \mathrm{~km}^{2}\end{array}$ & open & $\begin{array}{l}\text { TOUGH2-MP/ } \\
\text { ECO2N }\end{array}$ & $\begin{array}{l}10 \mathrm{Mt} \mathrm{yr}^{-1} \\
\text { over } \\
100 \text { years }\end{array}$ & $\mathrm{CO}_{2}$ & $\begin{array}{l}\text { Pressure build-up and } \\
\text { brine migration in the } \\
\text { reservoir and through } \\
\text { low permeable cap } \\
\text { rocks. }\end{array}$ & $\begin{array}{l}\text { - Pressure build-up of a } \\
\text { few bars can occur in the } \\
\text { shallow confined aquifers over } \\
\text { extensive regions. }\end{array}$ \\
\hline $\begin{array}{l}\text { Zhou et al. } \\
(2010)\end{array}$ & $\begin{array}{l}\text { - Illinois Basin, USA } \\
-241000 \mathrm{~km}^{2}\end{array}$ & open & $\begin{array}{l}\text { TOUGH2- } \\
\text { ECO2N }\end{array}$ & $\begin{array}{l}100 \mathrm{Mt} \mathrm{yr}^{-1} \\
\text { over } 50 \text { years }\end{array}$ & $\mathrm{CO}_{2}$ & $\begin{array}{l}\text { Pressure build-up and } \\
\mathrm{CO}_{2} \text { /brine migration } \\
\text { in the reservoir and } \\
\text { through low perme- } \\
\text { able cap rocks. }\end{array}$ & $\begin{array}{l}\text { - Pressure build-up of } 1 \text { and } \\
0.1 \text { bar can be expected as far } \\
\text { as } 150 \text { and } 300 \mathrm{~km} \text { from the in- } \\
\text { jection area, respectively. } \\
\text { - Pressure increase of } 35 \text { bar } \\
\text { at injection does not affect cap } \\
\text { rock integrity. }\end{array}$ \\
\hline This study & $\begin{array}{l}\text { - North German Basin } \\
-10000 \mathrm{~km}^{2}\end{array}$ & $\begin{array}{l}\text { closed and } \\
\text { open }\end{array}$ & $\begin{array}{l}\text { TOUGH2-MP/ } \\
\text { ECO2N }\end{array}$ & $\begin{array}{l}1.7 \mathrm{Mt} \mathrm{yr}^{-1} \\
\text { over } 20 \text { years }\end{array}$ & Water & $\begin{array}{l}\text { Brine migration } \\
\text { through fault zones } \\
\text { depending on differ- } \\
\text { ent geological condi- } \\
\text { tions. }\end{array}$ & $\begin{array}{l}\text { - Boundary conditions, fault } \\
\text { length and existence of an } \\
\text { overlying secondary reservoir } \\
\text { affect pressure build-up in the } \\
\text { reservoir and thereby freshwa- } \\
\text { ter salinisation. }\end{array}$ \\
\hline
\end{tabular}




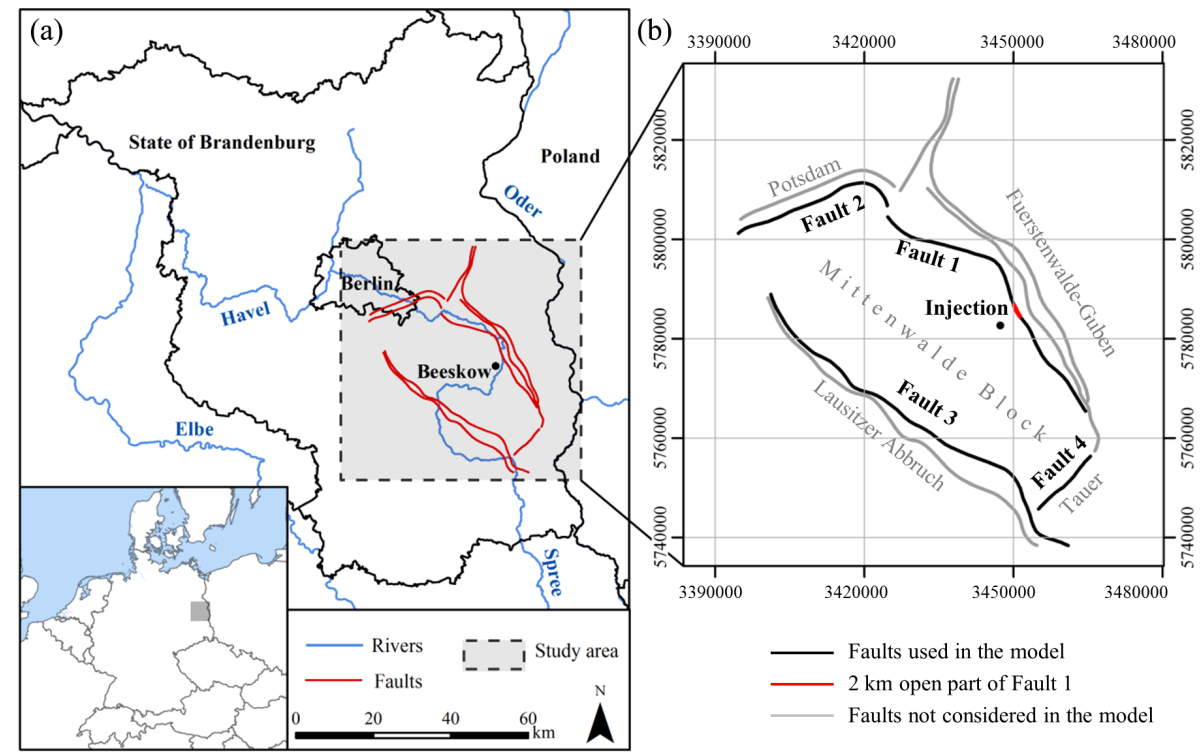

Figure 1. (a) Dashed rectangle indicates the location of the study area in the state of Brandenburg (Germany), while red lines illustrate the present fault systems. (b) Only the inner faults (black lines), facing to the injection well, were implemented to represent the entire fault zone. Axes show UTM-coordinates (WGS84/UTM zone 33N). Rivers and the outline of the states of Brandenburg and Berlin were derived from Tillner et al. (2013a).
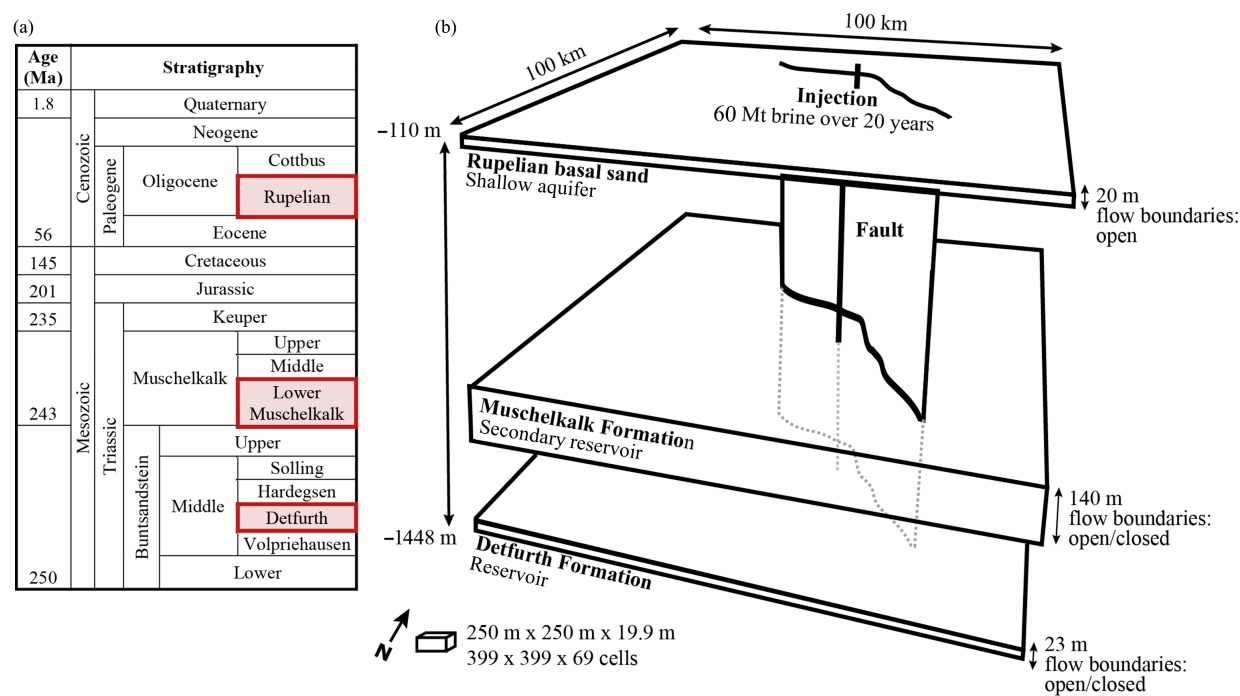

Figure 2. (a) Stratigraphy of the study area with the active model layers highlighted in red. (b) The geological 3-D model with simplified topography comprises up to three layers.

\section{Geological model}

We used the Petrel software package (Schlumberger, 2011) for the 3-D geological model construction and the subsequent gridding process, and the reservoir simulator TOUGH2MP/ECO2N for 3-D multi-component flow simulations (Pruess, 2005; Zhang et al., 2008). All simulations were conducted on a high-performance computing system with 256 cores. Finally, results were imported back into Petrel for visualisation purposes.

\subsection{Set-up}

The 3-D geological model has a horizontal extent of $100 \mathrm{~km} \times 100 \mathrm{~km}$ and a vertical thickness of $1340 \mathrm{~m}$. It consists of up to three layers: the Rupelian basal sand as the uppermost shallow aquifer, the Muschelkalk Formation as an overlying secondary reservoir and the Detfurth 
Table 2. Vertical grid discretisation, depth and hydraulic parameters for the active geological units.

\begin{tabular}{llllllll}
\hline Unit & Translation & $\begin{array}{l}\text { Permeability } \\
(\mathrm{mD})\end{array}$ & $\begin{array}{l}\text { Porosity } \\
(\%)\end{array}$ & $\begin{array}{l}\text { Thickness } \\
(\mathrm{m})\end{array}$ & $\begin{array}{l}\text { Depth } \\
(\mathrm{m})\end{array}$ & $\begin{array}{l}\text { Element layers } \\
\text { Vertical } \\
\text { resolution }(\mathrm{m})\end{array}$ \\
\hline $\begin{array}{l}\text { Rupelian basal sand } \\
\text { Muschelkalk Formation }\end{array}$ & Shallow aquifer & 1000 & 20 & 20 & -110 to -130 & 2 & 10 \\
Detfurth Formation & Secondary reservoir & 200 & 20 & 140 & -1025 to -1165 & 7 & 19.9 \\
\hline Faults & Reservoir & 400 & 17 & 23 & -1425 to -1448 & 2 & 11.5 \\
\hline
\end{tabular}

Formation as lowermost reservoir (Fig. 2b). The Rupelian basal sand is $20 \mathrm{~m}$ thick and located at a depth of $110 \mathrm{~m}$ (Grube et al., 2000). The Lower Muschelkalk Formation is at $1025 \mathrm{~m}$ depth and has a thickness of $140 \mathrm{~m}$, while the reservoir is at $1425 \mathrm{~m}$ depth with a thickness of $23 \mathrm{~m}$ (Tillner et al., $2013 a)$. Figure $2 b$ shows the geological model with a regular lateral grid resolution of $250 \mathrm{~m} \times 250 \mathrm{~m}$. The vertical discretisation depends on the different model layers, and ranges between 10 and $19.9 \mathrm{~m}$ (Table 2).

In a previous study, Kühn and Kempka (2015) investigated the influence of cap rock permeabilities on shallower aquifer salinisation at the prospective storage site Beeskow. Their results showed that for cap rock permeabilities equal to or lower than $10^{-17} \mathrm{~m}^{2}$ no increase in salt concentration in formations above the reservoir is to be expected. The top formation seal in the study area mainly consists of marine evaporates, such as anhydrite and halite, with a total thickness of up to $180 \mathrm{~m}$. We therefore defined the cap rocks as impermeable for fluid flow in all simulations. Thus, only the faults provide a hydraulic connection between the shallow aquifer and the reservoir. Accordingly, the elements of the faults as well as the different reservoir layers were "active" in the simulations, whereby the elements representing the cap rocks were not considered.

Within our model only the inner faults, which enclose the Mittenwalde Block, were implemented as a representation of the entire fault zone (Fig. 1b). Fault-related parameters were assigned to the elements located at the respective vertical fault plane. The fault element width of $250 \mathrm{~m}$ corresponds to the overall lateral grid resolution. This element width is relatively large but still realistic, since all regional fault zones consist of several individual faults and show considerable displacements between a few hundred metre to $1000 \mathrm{~m}$. In general, fault offset is linked to the width of the damage zone (Faulkner et al., 2010; Mitchel and Faulkner, 2009; Wibberley et al., 2008). For example, faults with displacements between 10 and $1000 \mathrm{~m}$ can have damage zone widths between tens and hundreds of metres. However, there exists no simple relationship, since the width of the damage zone is highly dependent on lithology, pressure, temperature and strain rate during shear and potentially tensile deformation (Shipton et al., 2006). Due to the relatively steep inclination of all faults and to maintain maximum grid regularity, the dip angle was neglected in the present model and all faults were assumed to be strictly vertical. In the following, the Fuerstenwalde-Guben fault zone is addressed as Fault 1. The Potsdam, the Lausitzer Abbruch and the Tauer fault zones are referred to as Faults 2, 3 and 4, respectively (Fig. 1b).

\subsection{Parameterisation}

All lithological units were parameterised according to Tillner et al. (2013a) and Vattenfall (2009), with values derived from borehole data and literature, and modelled as homogenous and isotropic. The Detfurth Formation has a permeability of $400 \mathrm{mD}$, while the overlying secondary reservoir (Muschelkalk Formation) is characterised by a permeability of $200 \mathrm{mD}$ (Table 2). Porosity and permeability of the Rupelian basal sand was chosen according to Tesch et al. (1987). Fault permeability was assumed higher than that of the host rock, because of fault-parallel permeability enhancement of the damage zone due to the presence of a fracture network (Jourde et al., 2002; Caine et al., 1996). A lateral barrier to groundwater flow due to a low permeable fault core was not directly considered in the simulations. However, as a conservative approach we assume that hydraulic properties of the fault damage zones are in between those of the Rupelian basal sand and the Detfurth Formation to promote upward brine displacement instead of cross-fault flow.

Because faults have a smaller offset at their boundaries, and consequently a less distinct damage zone, it was presumed that permeability declines in these areas. This was implemented into the model by using permeability multipliers in the respective elements. The permeability declines linearly towards the ends of the fault, applied to the first and last $15 \%$ of its length. In the following, the Detfurth Formation, Muschelkalk Formation and Rupelian basal sand are referred to as reservoir, secondary reservoir and shallow aquifer, respectively (Fig. 2b; Table 2).

\subsection{Initial and boundary conditions}

In all investigated scenarios, Dirichlet boundary conditions were applied to the shallow aquifer. These were implemented by volume multipliers of $10^{10}$ at the boundary elements of each layer, so that the aquifer has infinite extension. The boundaries of the reservoir and the secondary reservoir are either open (boundary element volume multiplication by $10^{5}$; quasi-infinite) or closed (no boundary element volume 
multiplication), depending on the investigated scenario. The higher volume multiplication at the boundary elements of the Tertiary shallow aquifer is based on the assumption that a continuous hydraulic connection throughout the formation is more likely in the younger and less consolidated sedimentary deposits than in the more tectonically influenced deeper rocks. For the temperature distribution, a constant geothermal gradient of $30^{\circ} \mathrm{C} \mathrm{km}^{-1}$ was used, starting from $15^{\circ} \mathrm{C}$ at the model top. All simulations were performed at isothermal conditions. Salinity is assumed to increase with depth either by a gradient of $0.23 \mathrm{~g} \mathrm{~kg}^{-1}$ solution per metre from zero at the base of the shallow aquifer up to a maximum of $25 \%$ at a depth of $1070 \mathrm{~m}$ (Vattenfall, 2009). A second realisation considers a sharp freshwater-saltwater interface at the base of the shallow aquifer with a constant salinity of $25 \%$. The latter conditions were chosen, as they lead to the maximum possible salinisation in the uppermost aquifer, and thus represent the most unfavourable scenario for shallow aquifers under the given assumptions.

In the respective industrial project at the Beeskow storage site, it was planned to inject $34 \mathrm{Mt}$ of $\mathrm{CO}_{2}$ over a time span of 20 years into the Mesozoic formations at the top of an anticline structure (Tillner et al., 2013a). In the present study, we chose a conservative approach and simulated the injection of the equivalent volume of brine into the storage formation, which enables us also to study the long-term effects of brine displacement more than 1000 years after the injection stop. Without topographic variations in the reservoir, $\mathrm{CO}_{2}$ is not immobilised in structural traps (e.g. below an anticline top) and might reach the Fuerstenwalde-Guben fault zone located at a distance of $4 \mathrm{~km}$ from the injection well over such a long simulation period. Potential $\mathrm{CO}_{2}$ leakage into overlying formations should not be the focus of investigation in the present study. In addition, initial testing has shown that the difference in pressure response at the fault from using a twophase model instead of single-phase model is small, compared to other effects studied here. Furthermore, with such a model we keep the findings of injection-related brine displacement transferable to various other types of subsurface storage. All simulations start from hydrostatic pressure conditions. Considering the density of brine, pressure at the top of the reservoir at $1425 \mathrm{~m}$ depth is approximately $165 \mathrm{bar}$. At a reservoir temperature of $58^{\circ} \mathrm{C}$, the resulting $\mathrm{CO}_{2}$ density is $668.5 \mathrm{~kg} \mathrm{~m}^{-3}$ (Span and Wagner, 1996). Taking into account the salinity of $25 \%$ in the reservoir, brine density is $1175 \mathrm{~kg} \mathrm{~m}^{-3}$. Thus, a volume equivalent mass of $59.76 \mathrm{Mt}$ brine was injected into the reservoir, corresponding to a rate of $94.6 \mathrm{~kg} \mathrm{~s}^{-1}$.

Brine densities are calculated in TOUGH2-MP/ECO2N for each element during the simulation and fluid compressibility is then considered by its density changes. Pore compressibility causes a higher storage coefficient in the formations when pressure increases. Since our simulations should show the greatest possible effect on brine displacement, pore compressibility was neglected. Assuming a fluid diffu- sion coefficient of $2 \times 10^{-9} \mathrm{~m}^{2} \mathrm{~s}^{-1}$ and a sharp freshwatersaltwater interface in the fault, it would take about 1 million years in the present model for the salinity front to propagate into a neighbouring element. We therefore neglected diffusion as well.

\section{Set of scenarios}

In total, 19 scenarios were selected to investigate the conditions for upward brine flow through the faults. Different fault lengths and permeabilities, hydrogeological boundary conditions and vertical salinity distributions, as well as the presence of a secondary reservoir formation above the target storage horizon, were considered. Scenarios are identified by the following abbreviations:

Scenario $=F_{n}^{l} B_{\mathrm{O} / \mathrm{C}} \mathrm{SR}_{k}$,

where $F$ denotes fault with the coefficients $l$ indicating the total fault length and $n$ the number of active faults. Further, the lateral boundary conditions $(B)$ of both reservoirs can be either open (O) or closed (C). SR denotes that an overlying secondary reservoir exists and $k$ specifies the permeability of that reservoir. Scenarios in which a salinity gradient was applied are marked with "*”. All simulated scenarios with their varying initial and boundary conditions are summarised in Tables 3 and 4.

The base cases consist of two layers, while three different fault lengths were considered. Either all four fault zones with a total length of $193 \mathrm{~km}$ were assumed to be permeable, or Fault 1 was defined to be hydraulically conductive with a length of $60 \mathrm{~km}$. In the third case, only a length of $2 \mathrm{~km}$ in the central part of Fault 1 was presumed to be open for fluid flow (Fig. 1b). Based on the effective porosity assumed for all fault zones and the total fault element volumes, the effective damage zone volume for the three different cases can be specified with $1.6 \times 10^{10} \mathrm{~m}^{3}$ (fault length of $193 \mathrm{~km}$ ), $4.9 \times 10^{9} \mathrm{~m}^{3}$ (fault length of $60 \mathrm{~km}$ ) and $1.8 \times 10^{8} \mathrm{~m}^{3}$ (fault length of $2 \mathrm{~km}$ ). For all these cases, scenarios with both open and closed reservoir boundaries as well as an overlying secondary reservoir were examined to illustrate the entire range of a potential freshwater salinisation depending on the given geological constraints.

\section{Results}

Results of injection-induced brine displacement via the faults are analysed at 20 years corresponding to the end of the injection period. At this time, reservoir pressures have reached their maximum, and thus effects on upward brine flow are most noticeable. In Sects. 5.2 to 5.5, salinity is assumed to increase sharply from zero in the shallow aquifer to $25 \%$ below that aquifer. In Sect. 5.6, the impact of a salinity gradient on shallow aquifer salinisation is presented. Here, salinity in 
Table 3. Overview of all calculated scenarios assuming a fault permeability of $700 \mathrm{mD}$. Maximum pressure increase at the base of Fault 1 and displacement depths in Fault 1 are observed at the central part of the fault.

\begin{tabular}{|c|c|c|c|c|c|c|c|c|}
\hline \multirow[b]{2}{*}{ Scenario } & \multirow[b]{2}{*}{$\begin{array}{l}\text { Fault length } \\
(\mathrm{km})\end{array}$} & \multirow[b]{2}{*}{$\begin{array}{l}\text { Effective dam- } \\
\text { age zone vol- } \\
\text { ume }\left(\mathrm{m}^{3}\right)\end{array}$} & \multirow[b]{2}{*}{$\begin{array}{l}\text { Pressure } \\
\text { increase at base } \\
\text { of Fault } 1 \text { (bar) }^{\mathrm{a}}\end{array}$} & \multirow[b]{2}{*}{$\begin{array}{l}\text { Maximum } \\
\text { displacement } \\
\text { depth in Fault } \\
1(\mathrm{~m})^{\text {ab }}\end{array}$} & \multicolumn{3}{|c|}{ Shallow aquifer } & \multirow[b]{2}{*}{$\begin{array}{l}\text { Duration of } \\
\text { mass flow } \\
\text { (years) }^{d}\end{array}$} \\
\hline & & & & & $\begin{array}{l}\text { Relative salt } \\
\text { mass change } \\
(\mathrm{kg})^{\mathrm{a}}\end{array}$ & $\begin{array}{l}\text { Salinisation } \\
\text { area }\left(\mathrm{km}^{2}\right)^{\mathrm{ac}}\end{array}$ & $\begin{array}{l}\text { Average salt } \\
\text { mass in salini- } \\
\text { sation area } \\
\left(\mathrm{kg} \mathrm{m}^{-2}\right)^{\mathrm{a}}\end{array}$ & \\
\hline$F_{1}^{2 \mathrm{~km}} B_{\mathrm{C}}$ & 2 & $1.8 \times 10^{8}$ & 19.0 & 131.7 & $6.17 \times 10^{9}$ & 19.8 & 311.6 & 330 \\
\hline$F_{1}^{2 \mathrm{~km}} B_{\mathrm{O}}$ & & & 12.4 & 105.4 & $4.86 \times 10^{9}$ & 16.4 & 296.3 & 31 \\
\hline$F_{1}^{2 \mathrm{~km}} B_{\mathrm{C}} \mathrm{SR}_{200 \mathrm{mD}}$ & & & 9.0 & 69.5 & $2.93 \times 10^{9}$ & 14.1 & 207.8 & 1050 \\
\hline$F_{1}^{2 \mathrm{~km}} B_{\mathrm{O}} \mathrm{SR}_{200 \mathrm{mD}}$ & & & 6.1 & 56.3 & $2.34 \times 10^{9}$ & 12.4 & 188.7 & 31 \\
\hline$F_{1}^{2} \mathrm{~km} B_{\mathrm{C}}^{*}$ & & & 18.9 & 131.7 & $5.80 \times 10^{8}$ & 21.1 & 27.5 & 275 \\
\hline$F_{1}^{60 \mathrm{~km}} B_{\mathrm{C}}$ & 60 & $4.9 \times 10^{9}$ & 12.1 & 29.8 & $1.08 \times 10^{10}$ & 76.5 & 141.2 & 115 \\
\hline$F_{1}^{60 \mathrm{~km}} B_{\mathrm{O}}$ & & & 9.7 & 28.4 & $8.45 \times 10^{9}$ & 67.3 & 125.6 & 31 \\
\hline$F_{1}^{60 \mathrm{~km}} B_{\mathrm{C}} \mathrm{SR}_{200 \mathrm{mD}}$ & & & 6.8 & 17.0 & $5.36 \times 10^{9}$ & 58.9 & 91.0 & 390 \\
\hline$F_{1}^{60 \mathrm{~km}} B_{\mathrm{O}} \mathrm{SR}_{200 \mathrm{mD}}$ & & & 5.3 & 16.3 & $4.16 \times 10^{9}$ & 50.9 & 81.7 & 40 \\
\hline$F_{1-4}^{193 \mathrm{~km}} B_{\mathrm{C}}$ & 193 & $1.6 \times 10^{10}$ & 11.0 & 28.6 & $1.23 \times 10^{10}$ & 146.1 & 84.2 & 66 \\
\hline$F_{1-4}^{1-4} \mathrm{~km} B_{\mathrm{O}}$ & & & 9.6 & 28.0 & $9.46 \times 10^{9}$ & 121.3 & 78.2 & 42 \\
\hline$F_{1-4}^{193 \mathrm{~km}} B_{\mathrm{C}} \mathrm{SR}_{200 \mathrm{mD}}$ & & & 6.4 & 16.5 & $6.64 \times 10^{9}$ & 114.0 & 58.3 & 225 \\
\hline$F_{1-4}^{1-4} \mathrm{~km} B_{\mathrm{O}} \mathrm{SR}_{200 \mathrm{mD}}$ & & & 5.3 & 16.1 & $4.59 \times 10^{9}$ & 90.1 & 50.9 & 45 \\
\hline$F_{1-4}^{193} \mathrm{~km}^{1-4} B_{\mathrm{O}} \mathrm{SR}_{2000 \mathrm{mD}}$ & & & 1.2 & 4.0 & $1.06 \times 10^{9}$ & 60.3 & 17.6 & 23 \\
\hline$F_{1-4}^{193 \mathrm{~km}} B_{\mathrm{C}}^{*}$ & & & 10.9 & 28.6 & $1.67 \times 10^{8}$ & 16.6 & 10.1 & 66 \\
\hline
\end{tabular}

Table 4. Overview of six scenarios assuming a sharp saltwater-freshwater interface below the base of the shallow aquifer and a fault permeability of 10, 200 and $700 \mathrm{mD}$. Maximum pressure increase at the base of Fault 1 and displacement depths in Fault 1 are again observed at the central part of the fault.

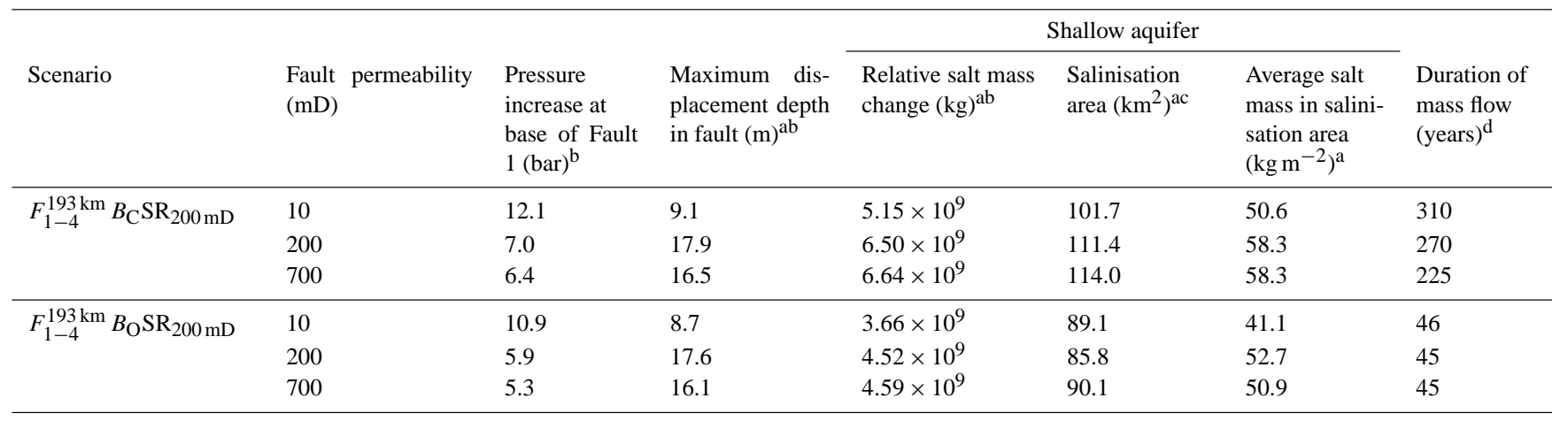

${ }^{\mathrm{a}} t=20$ years $;^{\mathrm{b}}$ counting from the base of the shallow aquifer; ${ }^{\mathrm{c}}$ salt concentration $>0.5 \mathrm{~g} \mathrm{~kg}^{-1}$ solution; ${ }^{\mathrm{d}}$ mass flow into the shallow aquifer $>0.1 \mathrm{~kg} \mathrm{~s}^{-1}$

the fault(s) increases from zero at the base of the shallow aquifer to a maximum of $25 \%$ at a depth of $1070 \mathrm{~m}$. Fault permeability is $700 \mathrm{mD}$ in all investigated scenarios, except for the comparison presented in Sect. 5.4, where duration of mass flow and shallow aquifer salinisation are also investigated for lower fault permeabilities of 10 and $200 \mathrm{mD}$. In Sect. 5.5, it is shown how a secondary reservoir with a permeability higher than that of the faults affects upward brine migration.

\subsection{General outcomes}

In all simulations, an injection-related pattern in pressure distribution and fluid flow can be observed. Figure 3 shows the mass flow of brine as an example for Scenario $F_{1-4}^{193 \mathrm{~km}} B_{\mathrm{O}}$ after 20 years. Starting from the injection location, brine is displaced radially within the reservoir, and hence predominantly into parts of the faults close to the point of injection. However, the trend of the four fault zones and the hydraulically conductive fault length impacts fluid flow out of the fault, and thus pressure gradients, so that brine distribution is not symmetric along the faults in the shallow aquifer. In case of four open faults, brine that flows out of the faults migrates into the Mittenwalde Block (compartment in the central model domain bounded by the four fault zones; Fig. 1) from all four fault zones and towards the open model boundaries. Consequently, pressure gradients are becoming lower 


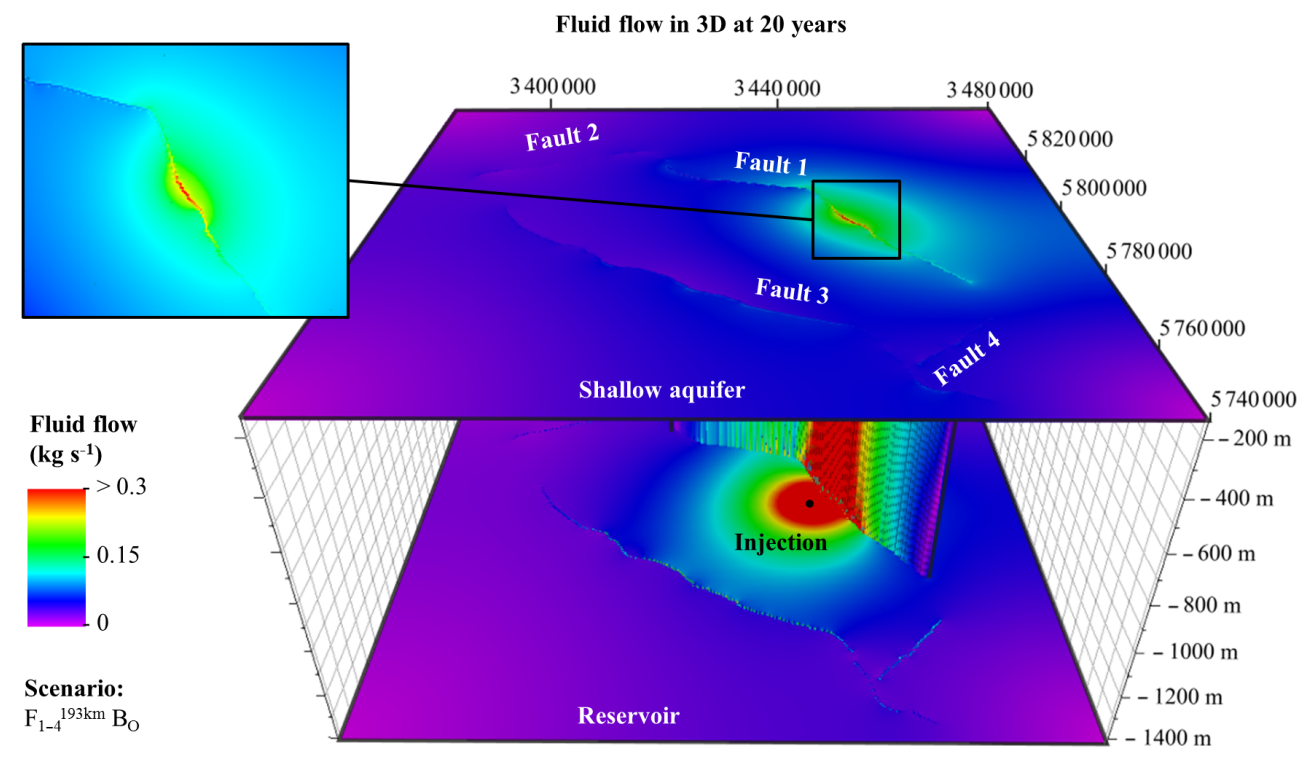

Figure 3. In all scenarios, brine is displaced radially within the reservoir and predominantly into parts of the faults lying closer to the injection well as illustrated for Scenario $F_{1-4}^{193 \mathrm{~km}} B_{\mathrm{O}}$.

in the Mittenwalde Block, so that flow out of all faults towards the lateral boundaries dominates at the final injection stage, since brine is displaced away from the point of the highest pressure build-up.

Duration and intensity of fluid flow determine the spatial distribution of displaced brine. In all scenarios, maximum mass flow is observed along Fault 1 close to the injection point decreasing towards the fault edges. This pattern is reflected in the salinisation of the freshwater aquifer, as shown in Fig. 4a. A maximum salinity in the shallow aquifer is reached at the end of the injection period in the central part of Fault 1, irrespective of whether a sharp saltwater-freshwater boundary at the base of the shallow aquifer (e.g. Scenario $F_{1-4}^{193 \mathrm{~km}} B_{\mathrm{C}}$ ) or a salinity gradient (Scenario $F_{1-4}^{193 \mathrm{~km}} B_{\mathrm{C}}^{*}$ ) was applied. Salt concentrations then decrease continuously towards the fault edges by more than $80 \%$. Salinity levels are generally the highest within the lower element layer, indicating that the denser saline water preferably spreads along the base of the aquifer (Fig. 4b). Decreasing upward brine displacement after the injection stop causes a downward flow of the denser saline water, which consequently accumulates at the base of the shallow aquifer. Moreover, a slight backflow into the fault occurs due to the increased weight of the water column. Hence, the salinity in the shallow aquifer slightly decreases after a simulated time of a few hundred years (Fig. 4b).

\subsection{Fault length/effective damage zone volume}

The impact of the hydraulic conductive fault length on shallow aquifer salinisation is presented in the following (Table 3).
Figure 5a shows that overpressures in the reservoir are generally the highest assuming laterally closed reservoir boundaries. The pressure development at the base of Fault 1 indicates that pressure increases until the injection stop after 20 years (Fig. 5b). In the case of a hydraulic conductive fault segment with a length of $2 \mathrm{~km}$ only, brine displacement, and thus pressure dissipation occurs over the smallest area. Consequently, the highest pressure build-up at the injection point ( 89.9 bar) and the base of Fault 1 (19.0 bar), into which brine is predominantly displaced, is observed for Scenario $F_{1}^{2 \mathrm{~km}} B_{\mathrm{C}}$ (Table 3). A greater effective fault damage zone volume reduces the pressure increase at the base of Fault 1 to 12.1 bar (Scenario $\left.F_{1}^{60 \mathrm{~km}} B_{\mathrm{C}}\right)$ and 10.9 bar $\left(F_{1-4}^{193 \mathrm{~km}} B_{\mathrm{C}}\right)$, respectively. Under the assumption of laterally open reservoir boundaries, pressure increase is reduced by a further $23 \%$ in average compared to all three cases with closed boundaries.

Saline water, migrating into the shallow aquifer, originates only from the fault(s) and not from greater depth. The higher the vertical pressure gradient, the greater the depth in the fault from which brine is displaced into the shallow aquifer. Hence, in Scenario $F_{1}^{2 \mathrm{~km}} B_{\mathrm{C}}$ saline water rises into the shallow aquifer from the upper $132 \mathrm{~m}$ of the fault, counting from the aquifer base (Table 3 ). This maximum displacement depth refers to the central part of Fault 1, where pressure gradients are the highest due to the proximity to the injection point. Displacement depths decrease towards the fault edges to partly less than $1 \mathrm{~m}$. The effect of this displacement depth is that the degree in salinisation in the shallow aquifer becomes locally higher with decreasing effective fault damage zone volume. In Scenario $F_{1}^{2 \mathrm{~km}} B_{\mathrm{C}}$, the average salt mass of the area that is affected by a salt concentration exceeding $0.5 \mathrm{~g} \mathrm{~kg}^{-1}$ solution (hereafter referred to as salin- 
(a) Salinity profile along Fault 1
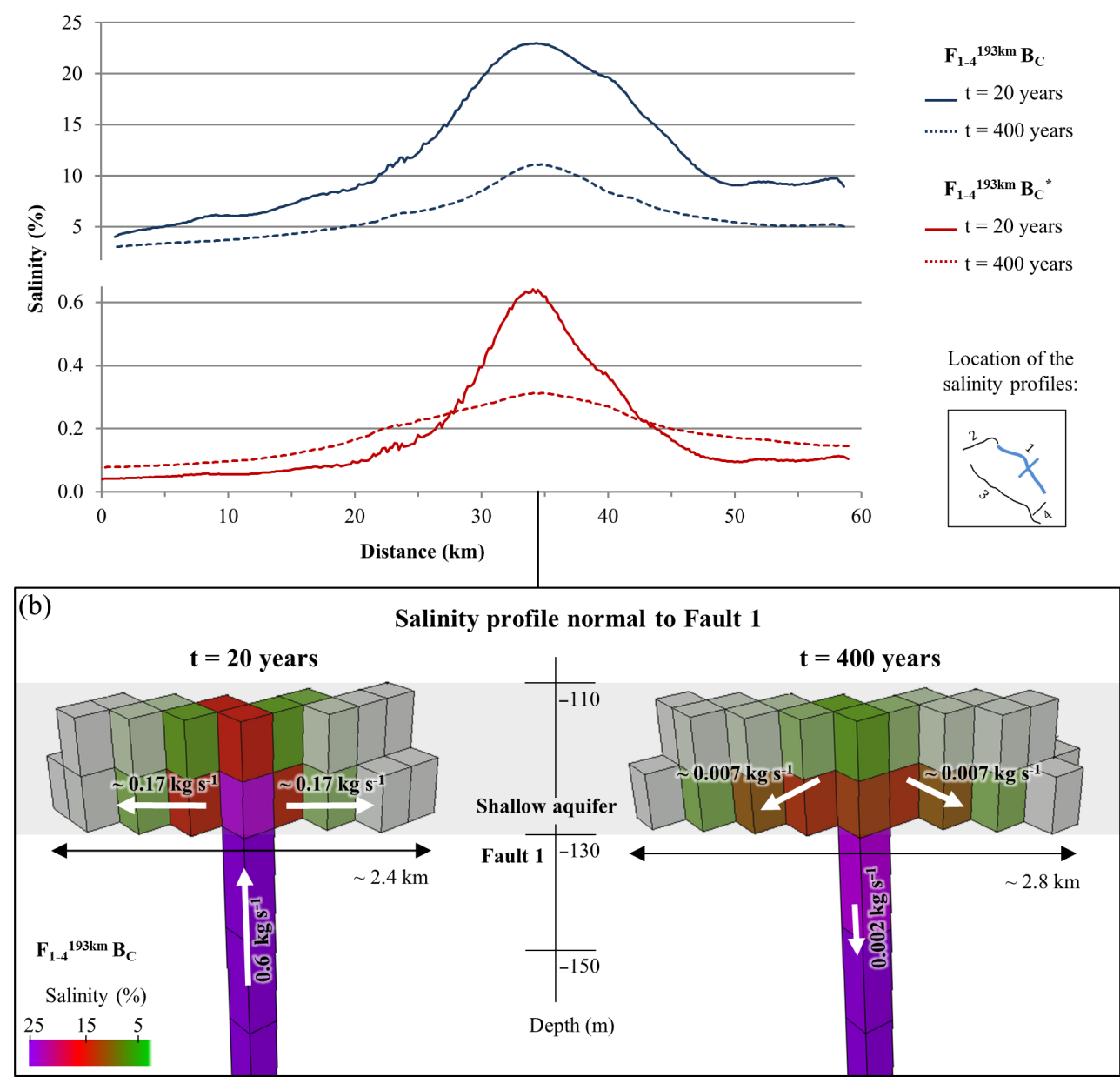

Figure 4. (a) Profile along Fault 1 shows the highest salinities in the central part of the fault near the injection well. Maximum salinities are significantly lower, if a salinity gradient is assumed (solid red line; Scenario $F_{1-4}^{193 \mathrm{~km}} B_{\mathrm{C}}^{*} ; y$ axis is not to scale). A decrease in salinisation due to a downward flow is observed for the time after the injection period and under the assumption of a sharp saltwater-freshwater interface (dashed blue line; Scenario $F_{1-4}^{193 \mathrm{~km}} B_{\mathrm{C}}$ ). (b) Cross section normal to Fault 1 illustrates the propagation of the saltwater plume in the shallow aquifer (salinities $>0.05 \%$ ), while higher salinities can be observed within the lower element layer. White arrows illustrate schematically the direction of fluid flow at 20 years and 400 years.

isation area), which corresponds to the maximum allowable limit prescribed by the German Drinking Water Ordinance (TrinkwV, 2001), is $312 \mathrm{~kg} \mathrm{~m}^{-2}$ after 20 years. In turn, the total salinisation area in the shallow aquifer is expectably larger the greater the fault length. In Scenario $F_{1-4}^{193 \mathrm{~km}} B_{\mathrm{C}}$, this area is more than 7 times as large as in Scenario $F_{1}^{2 \mathrm{~km}} B_{\mathrm{C}}(\mathrm{Ta}-$ ble 3). However, the salt mass per unit area is considerably lower, since pressure dissipation occurs over a greater hydraulic conductive fault length, which reduces pressure gradients and brine displacement depths in the faults $(30 \mathrm{~m}$ in Scenario $F_{1}^{60 \mathrm{~km}} B_{\mathrm{C}}$ and $29 \mathrm{~m}$ in Scenario $F_{1-4}^{193 \mathrm{~km}} B_{\mathrm{C}}$ ). Thus, the average salt mass of the salinisation area in the shallow aquifer is $141 \mathrm{~kg} \mathrm{~m}^{-2}$ in Scenario $F_{1}^{60 \mathrm{~km}} B_{\mathrm{C}}$ and $84 \mathrm{~kg} \mathrm{~m}^{-2}$ in Scenario $F_{1-4}^{193 \mathrm{~km}} B_{\mathrm{C}}$. Lower vertical pressure gradients in the fault in the case of laterally open reservoir boundaries reduce brine displacement depths and flow velocities out of the faults, and consequently the size of the salinisation areas and average displaced salt masses in the shallow aquifer compared to the scenarios with closed reservoir boundaries (Fig. 6).

After the injection stop, fluid flow persists until the overpressure in the reservoir is completely reduced. Duration of fluid flow and pressure reduction thereby depend on the lateral boundary conditions and the hydraulically conductive fault length. Pressure reduces substantially faster with increasing fault length and under the assumption of laterally open fluid flow boundaries that allow for horizontal brine displacement across the model boundaries (Fig. 5b). Hence, also the duration of brine displacement into the shallow aquifer is shorter in case of open reservoir boundaries. After 31 years 

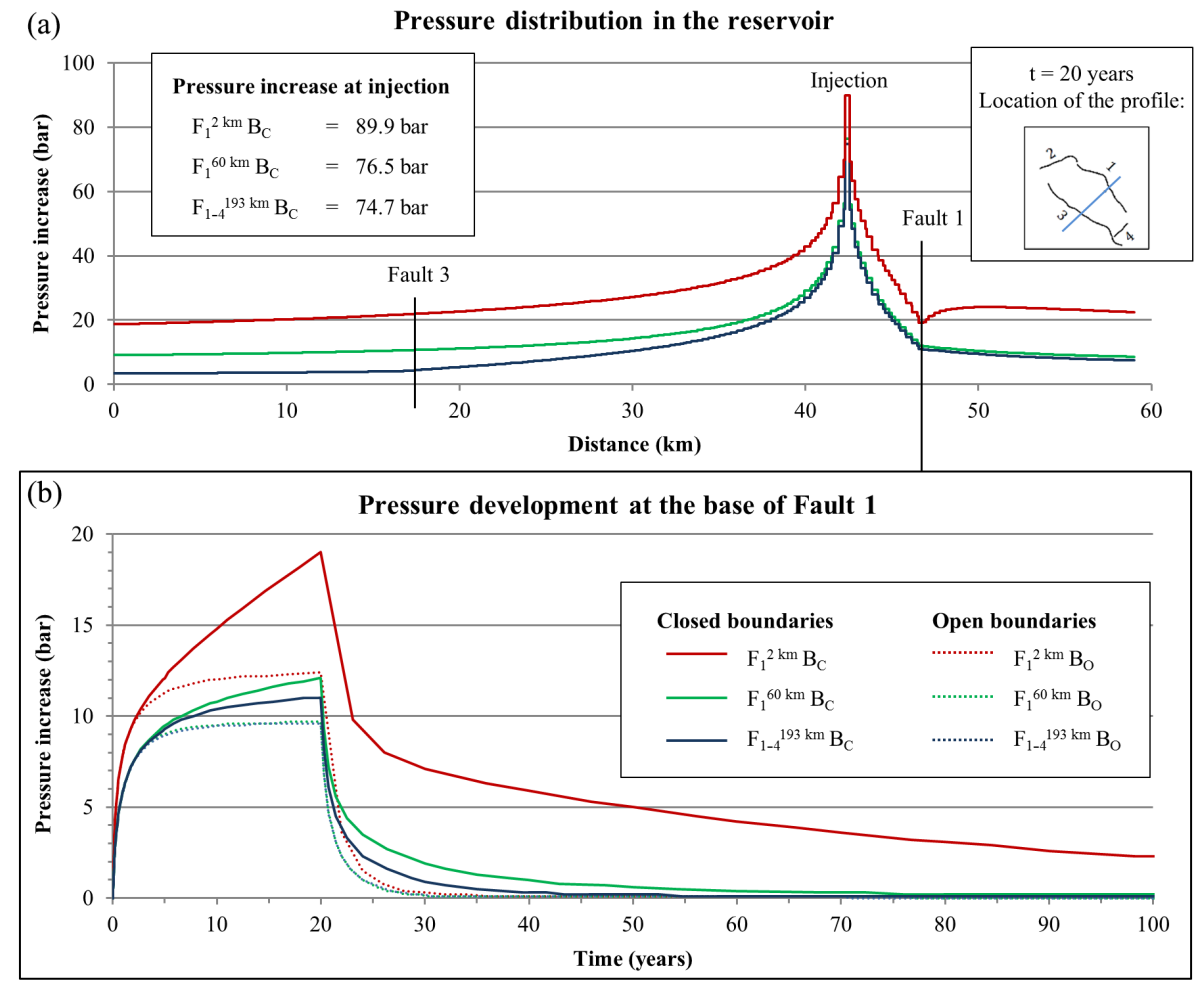

Figure 5. (a) Pressure distribution in the reservoir along the highlighted cross section significantly varies depending on the open fault length. The highest pressurisation is observed for a short fault $\left(F_{1}^{2 \mathrm{~km}} B_{\mathrm{C}}\right)$. (b) Pressure development at the base of Fault 1 indicates a substantially faster pressure reduction for greater fault lengths.

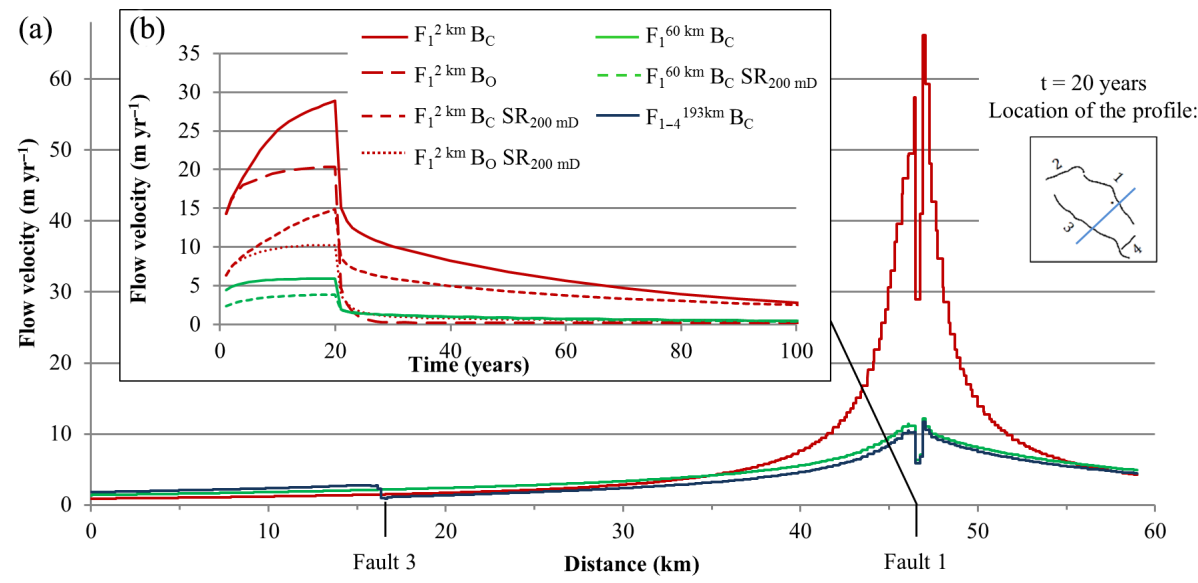

Figure 6. (a) Velocity profile within the lower element layer of the shallow aquifer shows the highest flow velocities out of Fault 1 at the end of injection period. (b) Flow velocities out of Fault 1 increase until the end of the injection period ( 20 years) and decrease afterwards depending on pressure reduction of the respective scenarios.

(Scenario $F_{1}^{2 \mathrm{~km}} B_{\mathrm{O}}$ ) to 42 years (Scenario $F_{1-4}^{193 \mathrm{~km}} B_{\mathrm{O}}$ ), pressure conditions prior to injection are re-established (Fig. 7a). In case of closed reservoir boundaries, pressure reduction in the incompressible domain solely comes from vertical brine displacement via the fault(s) towards the laterally infinite shallow aquifer. Thus, under the assumption of a sharp saltwater-freshwater boundary, the mass of salt displaced into the shallow aquifer corresponds to the overall injected salt mass (Fig. 7b). In this case, the open fault length affects only the duration of fluid migration, which can be between 66 years (Scenario $F_{1-4}^{193 \mathrm{~km}} B_{\mathrm{C}}$ ) and 330 years (Scenario $F_{1}^{2 \mathrm{~km}} B_{\mathrm{C}}$ ) (Fig. 7a). Decreasing vertical pressures, after upward brine migration stops at the end of injection, cause 
(a) Relative mass change in the shallow aquifer
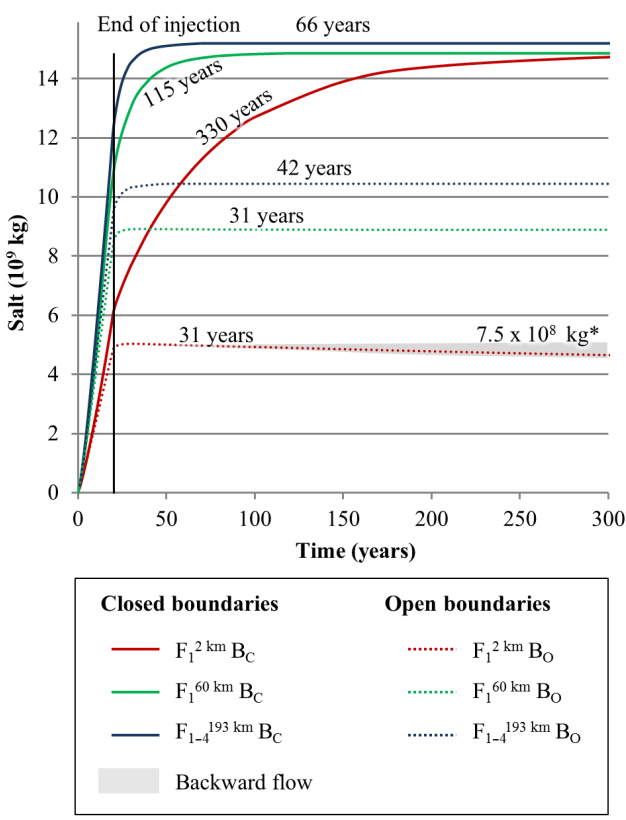

* Mass of (dissolved) salt flowing out of the shallow aquifer after 1000 years (b) Relative mass change for all units

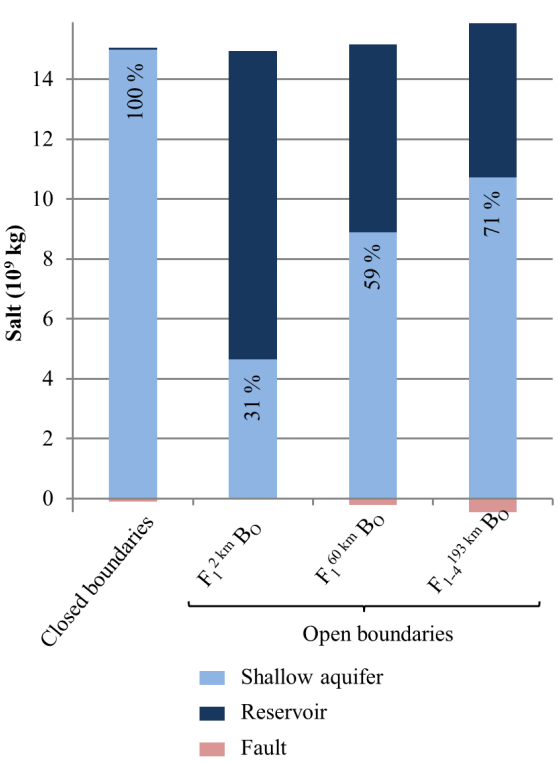

Figure 7. (a) Relative salt mass change in the shallow aquifer shows that the mass of salt displaced into that aquifer corresponds to the total salt mass of injected brine, if reservoir boundaries are closed. As indicated by the duration of mass flow (black numbers), only a temporal effect on fluid migration occurs. (b) Relative mass change for all lithological units after 20 years illustrates a considerably reduced salinisation of the shallow aquifer for open reservoir boundaries.

a slight backward flow of brine out of the shallow aquifer and back into the fault in the case of a small effective fault damage zone volume and laterally open reservoir boundaries. Over a period of 300 years, the salt mass in the shallow aquifer decreases by about $7.5 \times 10^{8} \mathrm{~kg}$ salt (Scenario $F_{1}^{2 \mathrm{~km}} B_{\mathrm{O}}$ ).

\subsection{Overlying secondary reservoir}

A secondary reservoir above the reservoir also hydraulically connected to the fault zones has a strong impact on pressure build-up within the injection horizon, and hence vertical pressure gradients in the fault(s). If reservoir boundaries are closed for fluid flow, the pressure increase at the base of Fault 1 ranges from $9.0 \mathrm{bar}\left(F_{1}^{2 \mathrm{~km}} B_{\mathrm{C}} \mathrm{SR}_{200 \mathrm{mD}}\right)$ to $6.4 \mathrm{bar}\left(F_{1-4}^{193 \mathrm{~km}} B_{\mathrm{C}} \mathrm{SR}_{200 \mathrm{mD}}\right)$, which corresponds to 47 and $58 \%$ of the pressure increase, respectively, without considering the overlying secondary reservoir. Under the assumption of laterally open reservoir boundaries, pressure increase is again reduced by further $24 \%$ on average, compared to all three cases with secondary reservoir and closed boundaries. This results in the lowest vertical pressure gradients in the fault(s) observed in the present scenario analysis. Lower reservoir pressures due to an overlying secondary reservoir induce lower flow velocities out of the fault as well, as shown in Fig. 6. Moreover, brine displaced into the shal- low aquifer originates from considerably shallower depths in the fault. Here, brine is displaced into the shallow aquifer from the upper $70 \mathrm{~m}$ of Fault 1 in Scenario $F_{1}^{2 \mathrm{~km}} B_{\mathrm{C}} \mathrm{SR}_{200 \mathrm{mD}}$ and $17 \mathrm{~m}$ in Scenario $F_{1-4}^{193 \mathrm{~km}} B_{\mathrm{C}} \mathrm{SR}_{200 \mathrm{mD}}$ considering laterally closed reservoir boundaries. Under the assumption of open flow boundaries, brine mainly originates from the upper $56 \mathrm{~m}$ (Scenario $F_{1}^{2 \mathrm{~km}} B_{\mathrm{O}} \mathrm{SR}_{200 \mathrm{mD}}$ ) and $16 \mathrm{~m}$ (Scenario $F_{1-4}^{193 \mathrm{~km}} B_{\mathrm{O}} \mathrm{SR}_{200 \mathrm{mD}}$ ) of the faults only. Consequently, the area affected by a salt concentration exceeding $0.5 \mathrm{~g} \mathrm{~kg}^{-1}$ solution in the shallow aquifer as well as the average salt mass in the salinisation area are reduced by about one-third compared to the respective scenario without considering a secondary reservoir (Table 3). Again, pressure conditions prior to injection re-establish fast after the injection stop and under the assumption of laterally open reservoir boundaries (e.g., 40 years for Scenario $F_{1}^{60 \mathrm{~km}} B_{\mathrm{O}} \mathrm{SR}_{200 \mathrm{mD}}$ ). In turn, the reduction of the comparatively lower overpressures takes significantly more time in case of laterally closed reservoir boundaries, e.g., the mass flow into the shallow aquifer continuous for about 225 years $\left(F_{1-4}^{193 \mathrm{~km}} B_{\mathrm{C}} \mathrm{SR}_{200 \mathrm{mD}}\right)$ and 1050 years $\left(F_{1}^{2 \mathrm{~km}} B_{\mathrm{C}} \mathrm{SR}_{200 \mathrm{mD}}\right)$, which is more than 3 times longer compared to the models without a secondary reservoir (Fig. 8). This retardation in fluid flow is attributable to the fact that the overpressure in both the injection horizon and secondary reservoir is successively reduced after the injection stop. Ac- 
(a)

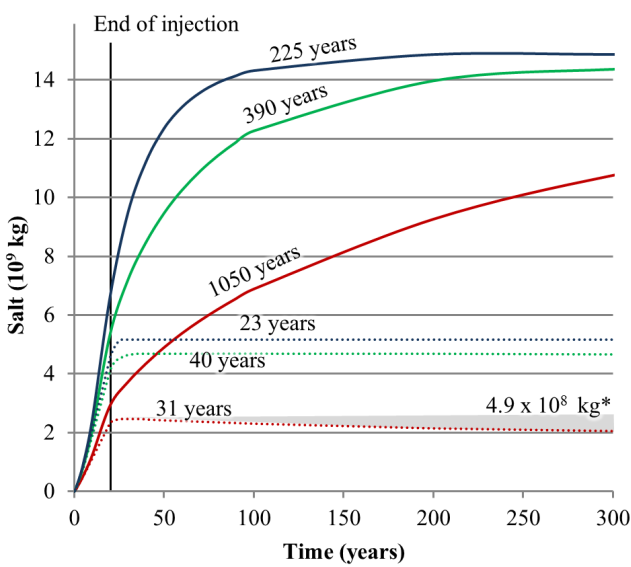

(b) Relative mass change for all units

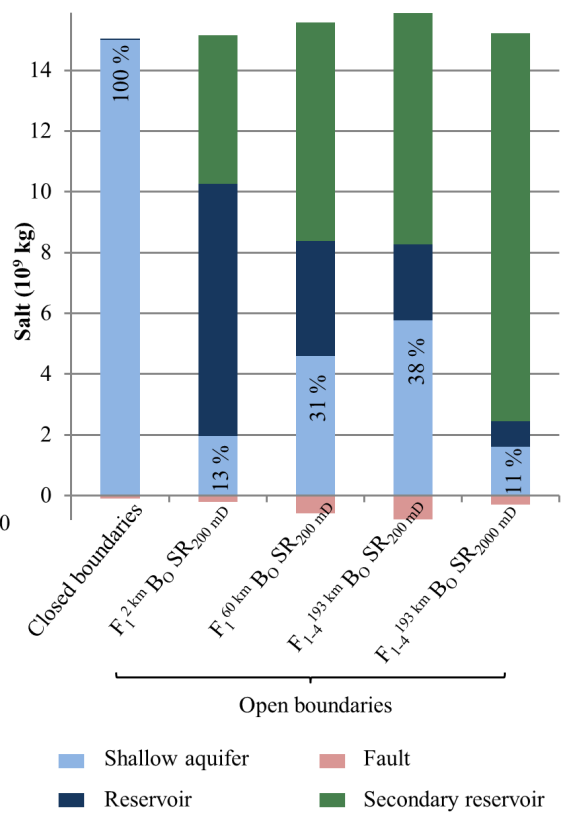

* Mass of (dissolved) salt flowing out of the shallow aquifer after 1000 years

Figure 8. (a) Temporal evolution of the relative salt mass change in the shallow aquifer shows a lower duration of mass flow for open reservoir boundary conditions. Further, a slight backward flow out of the aquifer can be observed if the hydraulically conductive fault length is small. (b) Relative salt mass change for lithological units at 1000 years (considering the backflow) illustrates that salinisation of the shallow aquifer is substantially reduced, if reservoir boundaries are open, and a further overlying secondary reservoir exists. Brine is preferentially displaced into the secondary reservoir, if the permeability of that reservoir exceeds fault permeability $\left(F_{1-4}^{193 \mathrm{~km}} B_{\mathrm{O}} \mathrm{SR}_{2000 \mathrm{mD}}\right)$. Consequently, freshwater salinisation in the shallow aquifer is the lowest compared to all other scenarios with a sharp saltwater-freshwater interface.

cording to the pressure gradient towards the shallow aquifer with laterally infinite extension, brine is displaced out of the secondary reservoir again after the injection stop and into the shallow aquifer (Fig. 9). Thus, the overall displaced salt mass in the shallow aquifer is almost identical compared to the corresponding scenarios without secondary reservoir, when pressure comes to an equilibrium (Figs. 7, 8).

\subsection{Fault permeability}

To evaluate the impact of fault permeability on upward brine displacement via the existing faults, a comparison was made between six scenarios that consider an effective damage zone volume of $1.6 \times 10^{10} \mathrm{~m}^{3}$ (total fault length of $193 \mathrm{~km}$ ) and a fault permeability of 10,200 and $700 \mathrm{mD}$ for laterally open and closed reservoir boundaries, respectively. Figure 12 and Table 4 show that the relative salt mass change in the shallow aquifer at the injection stop is almost identical for a fault permeability of 700 and $200 \mathrm{mD}$. Thereby, laterally open model boundaries reduce the average salt mass of the salinisation areas in the shallow aquifer by about $12 \%$ compared with the models using laterally closed boundaries. A less permeable fault with a permeability of $10 \mathrm{mD}$ has a more significant impact on the degree of upper aquifer salinisation. The relative salt mass change in the shallow aquifer after 20 years is $17 \%$ lower on average compared with a fault permeability of 200 or $700 \mathrm{mD}$. However, in a laterally closed and incompressible domain all the pressure relief comes from upward brine migration. Consequently, all the injected brine volume reaches the shallow aquifer after a certain time, since flow persists until the overpressure in the storage formation is completely reduced. In this case, a low-permeable fault only extends the duration of mass flow into the shallow aquifer, which can last for up to 310 years (Fig. 10; Table 4). At that time, the total salt mass displaced into the shallow aquifer is the same as for the scenarios with a fault permeability of 200 or $700 \mathrm{mD}$.

\subsection{Permeability difference between fault and secondary reservoir}

Our simulations demonstrate that if reservoir boundaries are closed, the permeability of the fault primarily influences the duration of fluid flow. After a certain period, the overall displaced salt mass into the freshwater aquifer becomes equal, if fault zones are sufficiently permeable. For this case, it is irrelevant if fault permeability is higher, equal or lower compared to the reservoir or aquifer. This is not true for open reservoir flow boundaries (infinite aquifer). In 


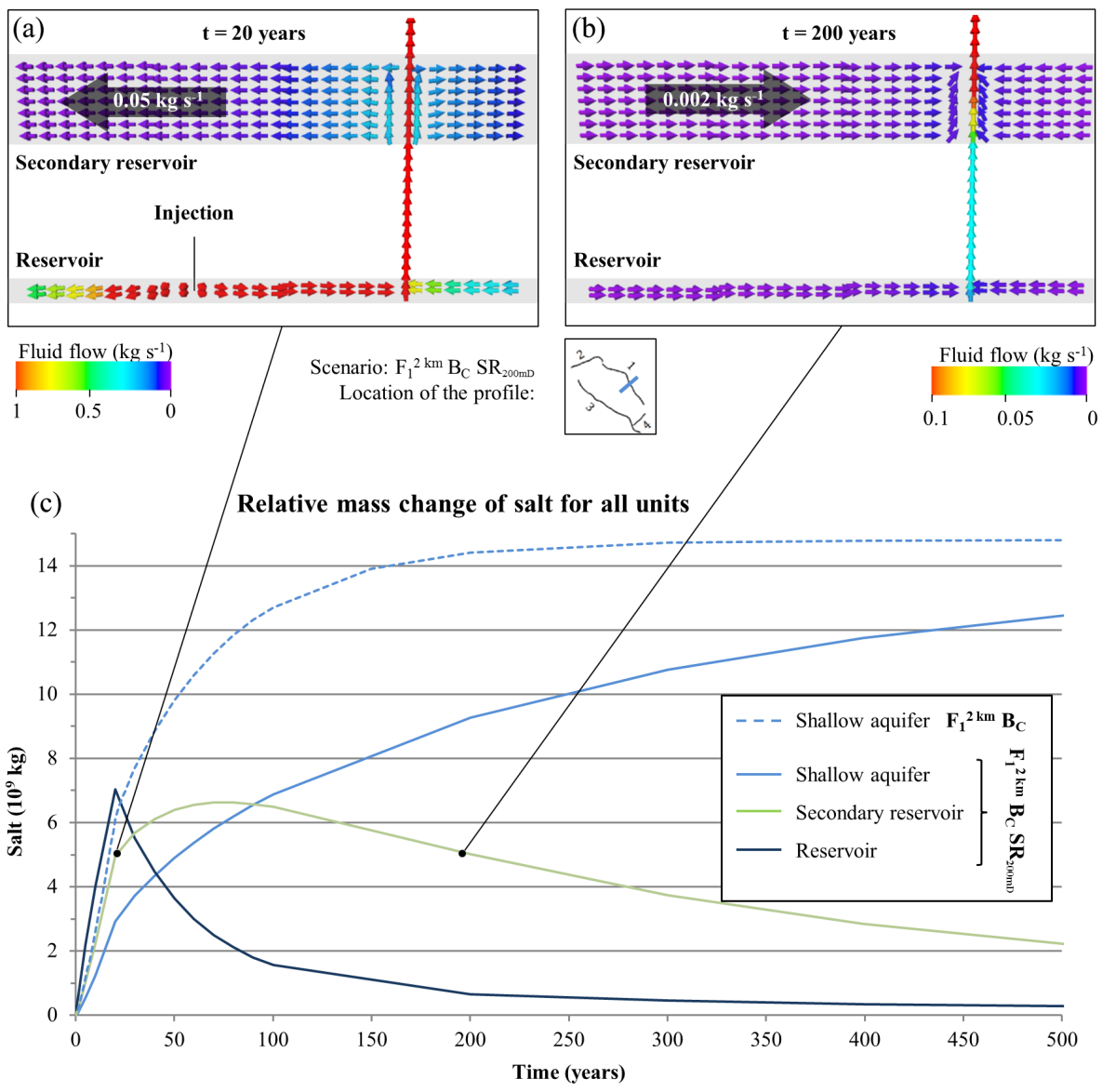

Figure 9. (a) Cross profile normal to Fault 1 shows that during the injection period the displaced fluid spreads within reservoir and overlying secondary reservoir. (b) Afterwards, the overpressure in both reservoirs is successively reduced and brine is transported out of the respective reservoir and into the shallow aquifer. (c) Temporal evolution of the relative salt mass change shows the resulting retardation in fluid flow into the shallow aquifer for Scenario $F_{1}^{2 \mathrm{~km}} B_{\mathrm{C}} \mathrm{SR}_{200 \mathrm{mD}}$.

Scenario $F_{1-4}^{193 \mathrm{~km}} B_{\mathrm{O}} \mathrm{SR}_{2000 \mathrm{mD}}$, the permeability of the secondary reservoir is distinctly higher than that of the fault. The pressure increase at the base of Fault 1 is only 1.2 bar, which corresponds to $23 \%$ of the total pressure increase, considering a secondary reservoir permeability of $200 \mathrm{mD}$ $\left(F_{1-4}^{193 \mathrm{~km}} B_{\mathrm{O}} \mathrm{SR}_{200 \mathrm{mD}}\right)$. Subsequently, brine that is displaced into the shallow aquifer originates solely from the upper $4 \mathrm{~m}$ of the faults. This results in the smallest salinisation area and the lowest degree in salinisation in the shallow aquifer compared to all other scenarios with a sharp saltwater-freshwater boundary (Fig. 9b; Table 3). In addition, the shortest duration of mass flow into the shallow aquifer with only 23 years is observed for Scenario $F_{1-4}^{193 \mathrm{~km}} B_{\mathrm{O}} \mathrm{SR}_{2000 \mathrm{mD}}$.

\subsection{Salinity gradient}

Two further scenarios, considering a total fault length of $2 \mathrm{~km}$ (Scenario $F_{1}^{2 \mathrm{~km}} B_{\mathrm{C}}^{*}$ ) and $193 \mathrm{~km}$ (Scenario $F_{1-4}^{193 \mathrm{~km}} B_{\mathrm{C}}^{*}$ ), without an overlying secondary reservoir and laterally closed reservoir boundaries were employed to investigate the im- pact of a salinity gradient on the degree of shallow aquifer salinisation. The pressure increase at the base of Fault 1 is almost identical comparing both scenarios with the corresponding scenario exhibiting a sharp saltwater-freshwater boundary below the Rupelian. Thus, a significant difference in the brine displacement depth in the faults cannot be observed after 20 years (Table 3). The displacement depth in the fault(s) is $132 \mathrm{~m}$ for Scenario $F_{1}^{2 \mathrm{~km}} B_{\mathrm{C}}^{*}$ and $29 \mathrm{~m}$ for Scenario $F_{1-4}^{193 \mathrm{~km}} B_{\mathrm{C}}^{*}$. Consequently, also the mass of brine displaced into the shallow aquifer after 20 years is very similar in the respective scenarios, with $2.2 \times 10^{10} \mathrm{~kg}$ (Scenario $F_{1}^{2 \mathrm{~km}} B_{\mathrm{C}}^{*}$ ) and $2.5 \times 10^{10} \mathrm{~kg}$ (Scenario $F_{1}^{2 \mathrm{~km}} B_{\mathrm{C}}$ ), as well as $4.1 \times 10^{10} \mathrm{~kg}$ (Scenario $F_{1-4}^{193 \mathrm{~km}} B_{\mathrm{C}}^{*}$ ) and $4.9 \times 10^{10} \mathrm{~kg}$ (Scenario $F_{1-4}^{193 \mathrm{~km}} B_{\mathrm{C}}$ ). However, the salt concentration of brine that is displaced out of the fault(s) and into the shallow aquifer is significantly lower when taking into account a salinity gradient instead of a sharp saltwater-freshwater interface. Hence, the average salt mass of the salinisation area in the shallow aquifer is only $9 \%$ (Scenario $F_{1}^{2 \mathrm{~km}} B_{\mathrm{C}}^{*}$ ) and 


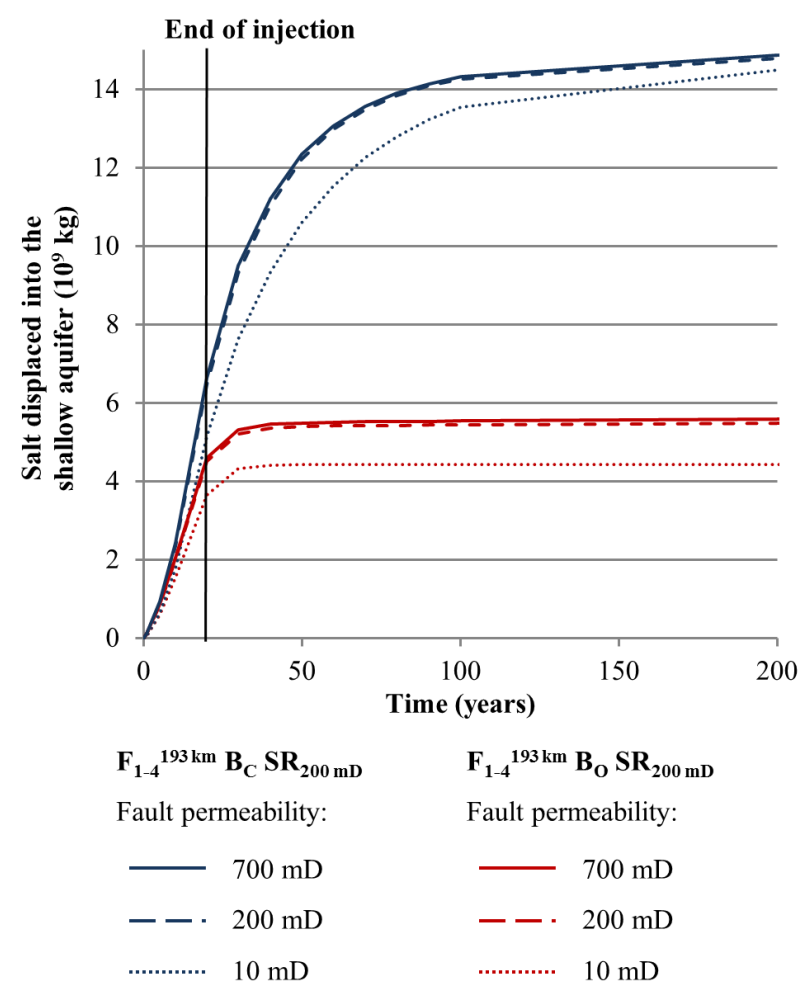

Figure 10. Salt mass displaced into the shallow aquifer assuming four open faults with varying permeability, a secondary overlying reservoir and open (red) or closed (blue) reservoir boundaries. The salt mass displaced into the shallow aquifer at the time of the injection stop and thereafter is almost identical for a fault permeability higher than (solid lines) or equal (dashed lines) to the permeability of the secondary reservoir. If fault permeability is lower than that of the secondary reservoir (dotted lines), less salt is displaced into the shallow aquifer. Closed reservoir boundaries and low-permeable faults lead to retardation in mass flow (blue dotted line).

$12 \%$ (Scenario $F_{1-4}^{193 \mathrm{~km}} B_{\mathrm{C}}^{*}$ ) of that in the respective scenarios with the sharp saltwater-freshwater boundary (Fig. 11; Table 3).

\section{Discussion}

The present study demonstrates how the presence of regional faults can affect upward brine displacement and the degree of shallow aquifer salinisation in geological subsurface utilisation. Different fault permeabilites, effective damage zone volumes, hydrogeological boundary conditions and vertical salinity distributions, as well as the presence of a secondary reservoir formation above the target storage horizon, are considered in a comprehensive large-scale scenario analysis. A 3-D geological model of a potential onshore storage site in the Northeast German Basin serves as the basis for this research. The results emphasise that maximum vertical pressure gradients in faults are observed for closed reservoir boundaries, if no overlying secondary reservoir exists and the effective fault damage zone volume is relatively small. The higher the vertical pressure gradient, the greater the depth in the faults from which brine is displaced into the shallow aquifer. A large effective fault damage zone volume, open reservoir boundaries and a secondary reservoir above the storage formation, also hydraulically connected to the fault zones, significantly reduce pressure gradients, and thus displacement depths in the faults. These depths range between $132 \mathrm{~m}$ (Scenario $\left.F_{1}^{2 \mathrm{~km}}{ }_{\mathrm{BC}}\right)$ and $4 \mathrm{~m}\left(F_{1-4}^{193 \mathrm{~km}} B_{\mathrm{O}} \mathrm{SR}_{2000 \mathrm{mD}}\right)$ after 20 years of fluid injection, respectively. Consequently, salt concentrations in the shallow aquifer are higher in the fault vicinity, the smaller the effective fault damage zone volume. The degree in salinisation thereby strongly depends on the initial salinity distribution in the fault. If salinity increases sharply from, e.g., zero in the shallow aquifer to $25 \%$ below its base, the average salt mass of the area affected by salinisation amounts to $312 \mathrm{~kg} \mathrm{~m}^{-2}$ after 20 years of injection (Scenario $F_{1}^{2 \mathrm{~km}}{ }_{\mathrm{BC}}$ ). A salinity gradient of $0.23 \mathrm{~g} \mathrm{~kg}^{-1}$ solution per metre reduces the average salt masses of the salinisation area in the shallow aquifer by more than $90 \%$ to $28 \mathrm{~kg} \mathrm{~m}^{-2}$ (Scenario $F_{1}^{2 \mathrm{~km}_{\mathrm{BC}}^{*}}$ ). On the contrary, the salinisation area in the shallow aquifer, assuming a total hydraulically conductive fault length of $193 \mathrm{~km}$ is 7 times larger than for a fault length of $2 \mathrm{~km}$. However, lower pressure gradients and brine displacement depths in the fault decrease the degree in salinisation in the shallow aquifer, since pressure dissipation occurs over a larger area.

In all scenarios, salinisation in the shallow aquifer was observed only along and in close proximity to the open fault zones up to a lateral extent of $2 \mathrm{~km}$ (Scenario $F_{1}^{2 \mathrm{~km}}{ }_{\mathrm{BC}}$; small effective fault damage zone volume) to a few hundred metres $\left(F_{1-4}^{193 \mathrm{~km}} B_{\mathrm{O}} \mathrm{SR}_{200 \mathrm{mD}}\right.$; large effective fault damage zone volume and secondary reservoir) from the fault. Brine that reaches the shallow groundwater system spreads preferentially at the aquifer base, as indicated by considerably higher salinities at the lower element layer in our simulations, which is in good agreement with the findings of Oldenburg and $\mathrm{Ri}-$ naldi (2011). Oldenburg and Rinaldi (2011) further showed that upward flux into the bottommost part of the shallow aquifer is sustained until a new hydrostatic equilibrium is reached, if the pressure elevation is high enough and the dense brine can spread unhindered in the upper aquifer. Our simulation results based on closed reservoir boundaries confirm these results. The mass of brine displaced into the shallow aquifer corresponds to the overall injected mass after several tens to hundreds of years, since the duration of brine displacement into the shallow aquifer is not limited to the injection period only. Laterally open reservoir boundaries and a large effective fault damage zone volume support a fast pressure reduction; however, brine displacement into the shallow aquifer persists for more than twice the injection period. Under the assumption of closed reservoir boundaries, all pressure relief results from upward brine migration via the faults. In this case, a small effective fault damage zone volume or a low permeable fault only extend the duration of brine flow 
Relative mass change in the shallow aquifer
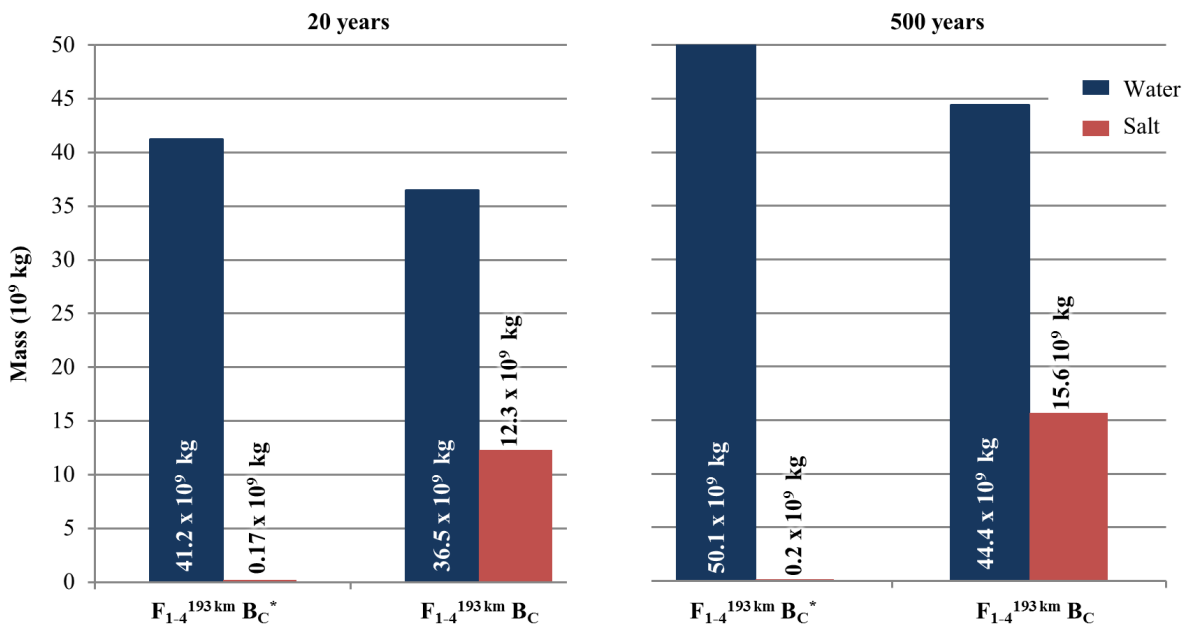

Figure 11. Relative mass change in the shallow aquifer after 20 years and 500 years for Scenario $F_{1-4}^{193 \mathrm{~km}} B_{\mathrm{C}}$ with a sharp saltwaterfreshwater boundary below the base of the shallow aquifer and Scenario $F_{1-4}^{193 \mathrm{~km}} B_{\mathrm{C}}^{*}$ with salinity increasing with depth by $0.23 \mathrm{~g} \mathrm{~kg}-1$ solution per metre up to a maximum of $250 \mathrm{~g} \mathrm{~kg}^{-1}$ at a depth of $1070 \mathrm{~m}$.

into shallower units, so that fluid flow can persist for more than 1000 years until the overpressure in the storage formation is completely reduced, resulting in an ongoing salinisation far beyond the time of the injection stop. This demonstrates the relevance of also considering the post-injection phase in salinisation assessments, since neglecting the ongoing fluid flow processes could lead to an underestimation of the potential freshwater salinisation. Nevertheless, it should be noted that regional groundwater flow and mixing with local recharge would probably have a strong effect on the reduction of salt concentrations in the shallow aquifer over a period of several hundred years. As demonstrated by the results, it is crucial to represent the site-specific geological conditions as close as possible. Cavanagh and Wildgust (2011) pointed out that storage formations are unlikely to have zeroflow boundaries and are rather open with respect to singlephase flow and pressure dissipation via brine displacement at regional scale.

In a previous study focusing on the same storage site, Tillner et al. (2013a) demonstrated that increasing fault permeability from 100 to $10000 \mathrm{mD}$ does not significantly affect the degree of shallow aquifer salinisation. Our simulations further show that only low fault permeability has a significant impact on upward brine migration. Depending on the lateral reservoir boundaries, the relative salt mass change in the shallow aquifer after 20 years is $13-22 \%$ lower for a fault permeability of $10 \mathrm{mD}$ compared with a fault permeability of $700 \mathrm{mD}$. Tillner et al. (2013a) mainly considered fault permeabilities higher than that of the reservoir and overlying permeable formations. Our simulations demonstrate that the preferential brine flow direction, and thus salinisation of upper aquifers is determined by the permeability contrast between fault and reservoir and/or overlying secondary reservoirs. If permeability of an overlying secondary reservoir exceeds that of the fault $\left(F_{1-4}^{193 \mathrm{~km}} B_{\mathrm{O}} \mathrm{SR}_{2000 \mathrm{mD}}\right)$, the mass of brine migrating into the shallow aquifer is only around a quarter of that observed in the opposite case $\left(F_{1-4}^{193 \mathrm{~km}} B_{\mathrm{O}} \mathrm{SR}_{200 \mathrm{mD}}\right)$. Thus, it can be concluded that in multi-barrier systems the potential salinisation of a shallow aquifer is lowered with each intermediate aquifer, if a hydraulic connection exists between the fault or leakage pathway and that aquifer. Similar results were achieved by an analytical approach of Nordbotten et al. (2004), investigating fluid leakage through wells in a multi-barrier system with up to 12 aquifers. The authors observed a successive decrease in the intensity of upward fluid displacement, caused by the migration of fluid into the intermediate aquifer layers, consequently reducing fluid migration in the shallowest aquifer. Birkholzer et al. (2009) also showed that the amount of fluid displaced into formations above the reservoir decreases in upward direction due to the attenuation capacity of the overlying rocks, however, without considering a vertical conduit. Further, Walter et al. (2012) concluded that saltwater intrusion into potable groundwater resulting from geological $\mathrm{CO}_{2}$ storage in a saline aquifer occurs most likely in the vicinity of vertical fluid conduits and not over large areas, if sites with multi-barrier systems and intermediate aquifers are selected. Zeidouni (2012) evaluated vertical communication between aquifers through a leaky fault by an analytical approach and showed that the attenuation capacity of a single, thick overlying aquifer is distinctly smaller than that of a multi-layered system.

In the present study, a conservative modelling approach in the assessment of potential upper aquifer salinisation by up- 
ward brine migration from saline formations was chosen. We injected brine instead of $\mathrm{CO}_{2}$ and neglected pore compressibility in our models to maximise pressurisation and related brine displacement. Considering the effects of $\mathrm{CO}_{2}$ and/or pore compressibility would induce a lower injection-related pressure build-up due to higher storage coefficients, and consequently to less intense brine displacement in the injection period. Furthermore, our simulations with a fault fully saturated with brine correspond to an endmember resulting in maximum freshwater salinisation. Brine migration across the faults is possible, since no impermeable fault core was considered; however, brine migration occurs almost solely upward into the overlying formations and is negligible in the horizontal direction across the faults, when applying a higher fault than reservoir permeability. Hence, the presented modelling results are valid for one specific fault architecture promoting vertical fluid flow, as a least favourable case with respect to shallow aquifer salinisation. In multi-layer systems with alternating layers of reservoirs and cap rocks, as that considered in the present study, fault permeability within the cap rock layers is usually lower than that of the fault host rocks resulting from the clay smearing effect (e.g., Crawford et al., 2008; Egholm et al., 2008). Fault permeability varies not only with mineralisation along the fault plane, but also with, e.g., depth, fault throw and orientation, inducing highly heterogeneous horizontal and vertical permeability patterns (e.g., Vilarrasa and Carrera, 2015; Bense and Person, 2006; Odling et al., 2004; Shipton and Cowie, 2003; Fisher and Knipe, 2001). Heterogeneity in fault permeability can prevent brine from migrating in an upward direction and result in much lower salt concentrations or a differently distributed salinisation pattern in the shallow aquifer as presented here. However, hydraulic properties and the spatial extent of fault damage zones are difficult to detect, and therefore exhibit a high uncertainty in predicting fault fluid flow and potentially resulting shallow freshwater salinisation (Odling et al., 2004; Harris et al., 2003). Further, geomechanical effects are relevant in the assessment of fault fluid flow and several authors have explored the impact of injection-induced pressure buildup on fault zones stability (e.g., Rinaldi et al., 2015; Kempka et al., 2014; Tillner et al., 2014; Magri et al., 2013; Röhmann et al., 2013; Cappa and Rutqvist, 2011; Chin et al., 2000). For this purpose, coupled hydro-mechanical simulations are applied to account for the interaction between hydraulic and mechanical processes, potentially triggering fault slip and dilation resulting in, e.g., new or enhanced leakage pathways for formation fluids. To minimise pressure perturbation due to fluid injection, and thus fault fluid flow, simultaneous fluid injection and production from storage reservoirs is discussed as one efficient mitigation measure to be applied in geological underground utilisation (Kempka et al., 2015b; Tillner et al., 2013b; Court et al., 2012; Bergmo et al., 2011; Buscheck et al., 2011).

For future investigations, we extend the assumptions made in the present study by the implementation of heterogeneous fault zones with spatial variations in porosity and permeability as well as related non-uniform architecture and fault inclination. Furthermore, research is underway to implement the 3-D model presented here in coupled hydro-mechanical simulations to account for potential fault shear failure and permeability changes that may alter fault fluid flow.

\section{Summary and conclusions}

In the present study, we demonstrate that pressure propagation in the reservoir determines the intensity and duration of fluid flow through the faults and shallow aquifer salinisation, mainly controlled by the lateral model boundary settings and the effective fault damage zone volume. In general, the potential of freshwater salinisation is low for greater effective fault damage zone volumes or fault lengths, because the origin depth of the fluids displaced into the shallow aquifer is located a few decametres below the shallow aquifer in maximum due to relatively low vertical pressure gradients. Short and very permeable fault segments or a small effective fault damage zone may result in a higher salinisation potential due to a larger vertical fault height affected by fluid displacement. The degree in shallow aquifer salinisation thereby strongly depends on the initial salinity distribution in the investigated area and especially that in the fault. If a gradient in salinity exists or the saltwater-freshwater interface lies below the fluid displacement depth in the faults, freshwater salinisation is considerably lower compared to scenarios with a sharp freshwater-brine interface located directly below the shallow freshwater aquifer. Moreover, it can be concluded that intermediate aquifers, lying in between the storage reservoir and the shallow freshwater aquifer, further diminish salinisation in the shallow aquifer because brine originating from the faults is partly displaced into these intermediate layers. Lateral boundary conditions mainly influence the duration of brine displacement: while open reservoir boundaries allow for fast pressure dissipation, fluid flow persists for several hundred to a thousand years in a spatially restricted reservoir until the mass of brine displaced into the shallow aquifer corresponds to the overall injected fluid mass (assuming zero pore compressibility). Considering our simulation results, we conclude that hydraulically conductive fault zones do not necessarily lead to freshwater salinisation owing to upward brine displacement. This principally depends on the initial salinity distribution, effective volume of the fault damage zone and the hydrogeological boundary conditions.

We demonstrated how to apply numerical simulations to provide site-specific insights on the relevant factors affecting dynamic fluid flow processes and brine displacement into shallow freshwater aquifers. Since most storage sites are very complex from the geological point of view, and especially the spatial distribution of heterogeneities in the subsurface at the regional scale is not well known, we focused here on selected parameter endmembers to estimate the site-specific 
bandwidth of potential freshwater salinisation. Field explorations have to be employed prior to any subsurface utilisation to obtain the most accurate data, especially on hydraulic properties of existing fault zones as well as the initial salinity distribution.

Acknowledgements. We would like to thank three anonymous reviewers for the support in improving the manuscript's quality and our colleagues Benjamin Nakaten and Marco De Lucia (GFZ German Research Centre for Geosciences) for technical support and constructive comments.

The article processing charges for this open-access

publication were covered by a Research

Centre of the Helmholtz Association.

Edited by: M. Riva

\section{References}

Bense, V. F. and Person, M. A.: Faults as conduit-barrier systems to fluid flow in siliciclastic sedimentary aquifers, Water Resour. Res., 47, W05421, doi:10.1029/2005WR004480, 2006.

Bergmo, P. E. S., Grimstad, A.-A., and Lindeberg, E.: Simultaneous $\mathrm{CO}_{2}$ injection and water production to optimise aquifer storage capacity, Int. J. Greenh. Gas Con., 5, 555-564, doi:10.1016/j.ijggc.2010.09.002, 2011.

Beutler, G. and Stackebrandt, W.: Der Schollenbau des Tafeldeckgebirges von Brandenburg - Vorschlag für eine einheitliche Benennung [The tectonic pattern of the sedimentary cover of Brandenburg - suggestion for a uniform nomenclature], Brandenburgische Geowissenschaftliche Beiträge, 19, 93-109, 2012.

Birkholzer, J. T., Zhou, Q., and Tsang, C.-F.: Large-scale impact of $\mathrm{CO}_{2}$ storage in deep saline aquifers: a sensitivity study on pressure response in stratified systems, Int. J. Greenh. Gas Con., 3, 181-194, doi:10.1016/j.ijggc.2008.08.002, 2009.

Birkholzer, J. T., Nicot, J. P., Oldenburg, C. M., Zhou, Q., Kraemer, S., and Bandilla, K.: Brine flow up a well caused by pressure perturbation from geologic carbon sequestration: static and dynamic evaluations, Int. J. Greenh. Gas Con., 5, 850-861, doi:10.1016/j.ijggc.2011.01.003, 2011.

Buscheck, T. A., Sun, Y., Hao, Y., Wolery, T. J., Bourcier, W., Tompson, A. F. B., Jones, E. D., Friedmann, S. J., and Aines, R. D.: Combining brine extraction, desalination, and residualbrine reinjection with $\mathrm{CO}_{2}$ storage in saline formations: Implications for pressure management, capacity, and risk mitigation, Energy Procedia, 4, 4283-4290, doi:10.1016/j.egypro.2011.02.378, 2011.

Caine, J., Evans, J., and Forster, C.: Fault zone architecture and permeability structure, Geology, 24, 1025-1028, doi:10.1130/00917613(1996)024<1025:FZAAPS>2.3.CO;2, 1996.

Cappa, F. and Rutqvist, J.: Modeling of coupled deformation and permeability evolution during fault reactivation induced by deep underground injection of $\mathrm{CO}_{2}$, Int. J. Greenh. Gas Con., 5, 336346, doi:10.1016/j.ijggc.2010.08.005, 2011.
Cavanagh, A. and Wildgust, N.: Pressurization and brine displacement issues for deep saline formation $\mathrm{CO}_{2}$ storage, Energy Procedia, 4, 4814-4821, doi:10.1016/j.egypro.2011.02.447, 2011.

Chin, L. Y., Raghavan, R., and Thomas, L. K.: Fully coupled geomechanics and fluid-flow analysis of wells with stressdependent permeability, SPE J., 5, 32-45, doi:10.2118/58968PA, 2000.

Chiaramonte, L., Zoback, M. D., Friedmann, S. J., and Stamp, V.: Seal integrity and feasibility of $\mathrm{CO}_{2}$ sequestration in the Teapot Dome EOR Pilot: Geomechanical site characterization, Environ. Geol., 54, 1667-1675, doi:10.1007/s00254-007-0948-7, 2008.

Court, B., Bandilla, K. W., Celia, M. A., Buscheck, T. A., Nordbotten, J. M., Dobossy, M., and Janzen, A.: Initial evaluation of advantageous synergies associated with simultaneous brine production and $\mathrm{CO}_{2}$ geological sequestration, Int. J. Greenh. Gas Con., 8, 90-100, doi:10.1016/j.ijggc.2011.12.009, 2012.

Crawford, B. R., Faulkner, D. R., and Rutter, E. H.: Strength, porosity, and permeability development during hydrostatic and shear loading of synthetic quartz-clay fault gouge, J. Geophys. Res.Sol. Ea., 113, B03207, doi:10.1029/2006JB004634, 2008.

Dempsey, D., Kelkar, S., and Pawar, R.: Passive injection: A strategy for mitigating reservoir pressurization, induced seismicity and brine migration in geologic $\mathrm{CO}_{2}$ storage, Int. J. Greenh. Gas Con., 28, 96-113, doi:10.1016/j.ijggc.2014.06.002, 2014.

Egholm, D. L., Clausen, O. R., Sandiford, M., Kristensen, M. B., and Korstgård, J. A.: The mechanics of clay smearing along faults, Geology, 36, 787-790, doi:10.1130/G24975A.1, 2008.

Faulkner, D. R., Jackson, C. A. L., Lunn, R. J., Schlische, R. W., Shipton, Z. K., Wibberley, C. A. J., and Withjack, M. O.: A review of recent developments concerning the structure, mechanics and fluid flow properties of fault zones, J. Struct. Geol., 32, 1557-1575, doi:10.1016/j.jsg.2010.06.009, 2010.

Fisher, Q. J. and Knipe, R. J.: The permeability of faults within siliciclastic petroleum reservoirs of the North Sea and Norwegian Continental Shelf, Mar. Petrol. Geol., 18, 1063-1081, doi:10.1016/S0264-8172(01)00042-3, 2001.

Fitts, J. P. and Peters, C. A.: Caprock Fracture Dissolution and $\mathrm{CO}_{2}$ Leakage, Rev. Mineral. Geochem., 77, 459-479, doi:10.2138/rmg.2013.77.13, 2013.

Forster, C. B. and Evans, J. P.: Fluid flow in thrust faults and crystalline thrust sheets: Results of combined field and modeling studies, Geophys. Res. Lett., 18, 979-982, 1991.

Grube, A., Wichmann, K., Hahn, J., and Nachtigall, K.: Geogene Grundwasserversalzung in den Poren-Grundwasserleitern Norddeutschlands und ihre Bedeutung für die Wasserwirtschaft, DVGW-Technologiezentrum Wasser, Band 9, Karlsruhe, 2000.

Hannemann, M. and Schirrmeister, W.: Paläohydrogeologische Grundlagen der Entwicklung der Süß-/Salzwassergrenze und der Salzwasseraustritte in Brandenburg [Paleohydrological basics of the development of the boundary of fresh and salt water as well as of the salt water-outlets in Brandenburg], Brandenburgische Geowissenschaftliche Beiträge, 5, 61-72, 1998.

Harris, S. D., McAllister, E., Knipe, R. J., and Odling, N. E.: Predicting the three-dimensional population characteristics of fault zones: a study using stochastic models, J. Struct. Geol., 25, 1281-1299, doi:10.1016/S0191-8141(02)00158-X, 2003.

Hotzan, G. and Voss, T.: Komplexe hydrogeochemisch-genetische Kartierung zur Einschätzung der Salzwassergefährdung pleistozäner und tertiärer Grundwasserleiter im Raum Storkow- 
Frankfurt (Oder)-Eisenhüttenstadt [Complex hydrogeochemicgenetic mapping for evaluation of the endangerment of pleistocene and tertiary aquifers by saline waters in the region Storkow-Frankfurt (Oder)-Eisenhüttenstadt], Brandenburgische Geowissenschaftliche Beiträge, 20, 62-82, 2013.

IEA Greenhouse Gas R\&D Programme (IEA GHG): CCS Site Characterization Criteria, Technical Study, Report No. 2009/10, 130 pp., 2008.

IPCC - Metz, B., Davidson, O., de Coninck, H.C., Loos, M. and Meyer L.A. (Eds.): IPCC Special Report on Carbon Dioxide Capture and Storage, Prepared by Working Group III of the Intergovernmental Panel on Climate Change, Cambridge University Press, New York, 431 pp., 2005.

Jourde, H., Flodin, E., Aydin, A., Durlovsky, L., and Wen, X.: Computing permeability of fault zones in eolian sandstone from outcrop measurements, AAPG Bull., 86, 1187-1200, doi:10.1306/61EEDC4C-173E-11D78645000102C1865D, 2002.

Kempka, T., Klapperer, S., and Norden, B.: Coupled hydromechanical simulations demonstrate system integrity at the Ketzin pilot site for $\mathrm{CO}_{2}$ storage, in: Rock Engineering and Rock Mechanics: Structures in and on Rock Masses; Proceedings of EUROCK 2014, ISRM European Regional Symposium, edited by: Alejano, L., Perucho, A., Olalla, C., and Jiménez, R., Leiden: CRC Press/Balkema, 1317-1322, 2014.

Kempka, T., Herd, R., Huenges, E., Endler, R., Jahnke, C., Janetz, S., Jolie, E., Kühn, M., Magri, F., Meinert, P., Moeck, I., Möller, M., Muñoz, G., Ritter, O., Schafrik, W., Schmidt-Hattenberger, C., Tillner, E., Voigt, H.-J., and Zimmermann, G.: Joint Research Project Brine: Carbon Dioxide Storage in Eastern Brandenburg: Implications for Synergetic Geothermal Heat Recovery and Conceptualization of an Early Warning System Against Freshwater Salinization, in: Geological Storage of $\mathrm{CO}_{2}$ - Long Term Security Aspects, edited by: Liebscher, A. and Münch, U., GEOTECHNOLOGIEN Science Report No.22, Advanced Technologies in Earth Sciences, Springer International Publishing, 139-166, 2015a.

Kempka, T., Nielsen, C. M., Frykman, P., Shi, J.-Q., Bacci, G., and Dalhoff, F.: Coupled Hydro-Mechanical Simulations of $\mathrm{CO}_{2}$ Storage Supported by Pressure Management Demonstrate Synergy Benefits from Simultaneous Formation Fluid Extraction, Oil Gas Sci. Technol., 70, 599-613, doi:10.2516/ogst/2014029, 2015 b.

Kühn, M. and Kempka, T.: $\mathrm{CO}_{2}$ Pressurisation of a Storage Reservoir does not Lead to Salinization of Shallower Aquifers through Intact Caprocks, Energy Procedia, 76, 607615, doi:10.1016/j.egypro.2015.07.880, 2015.

Magri, F., Tillner, E., Wang, W., Watanabe, N., Zimmermann, G., and Kempka, T.: 3-D Hydro-mechanical Scenario Analysis to Evaluate Changes of the Recent Stress Field as a Result of Geological $\mathrm{CO}_{2}$ Storage, Energy Procedia, 40, 375-383, doi:10.1016/j.egypro.2013.08.043, 2013.

Mitchell, T. and Faulkner, D.: The nature and origin of offfault damage surrounding strike-slip fault zones with a wide range of displacements: A field study from the Atacama fault system, northern Chile, J. Struct. Geol., 31, 802-816, doi:10.1016/j.jsg.2009.05.002, 2009.

Nakaten, B., Tillner, E., and Kempka, T.: Virtual Elements for Representation of Faults, Cracks and Hydraulic Fractures in
Dynamic Flow Simulations, Energy Procedia, 40, 447-453, doi:10.1016/j.egypro.2013.08.051, 2013.

Nicot, J.: Evaluation of large-scale $\mathrm{CO}_{2}$ storage on freshwater sections of aquifers: An example from the Texas Gulf Coast Basin, Int. J. Greenh. Gas Con., 2, 582-593, doi:10.1016/j.ijggc.2008.03.004, 2008.

Nordbotten, J. M., Celia, M. A., and Bachu, S.: Analytical solutions for leakage rates through abandoned wells, Water Resour. Res., 40, W04204, doi:10.1029/2003WR002997, 2004.

Odling, N. E., Harris, S. D., and Knipe, R. J.: Permeability scaling properties of fault damage zones in siliclastic rocks, J. Struct. Geol., 26, 1727-1747, doi:10.1016/j.jsg.2004.02.005, 2004.

Oldenburg, C. M. and Rinaldi, A. P.: Buoyancy Effects on Upward Brine Displacement caused by $\mathrm{CO}_{2}$ Injection, Transport Porous. Med., 87, 525-550, doi:10.1007/s11242-010-9699-0, 2011.

Person, M., Banerjee, A., Rupp, J., Medina, C., Lichtner, P., Gable, C., Pawar, R., Celia, M., McIntosh, J., and Bense, V.: Assessment of basin-scale hydrologic impacts of $\mathrm{CO}_{2}$ sequestration, Illinois basin, Int. J. Greenh. Gas Con., 4, 840-854, doi:10.1016/j.ijggc.2010.04.004, 2010.

Pruess, K.: ECO2N: A TOUGH2 Fluid Property Module for Mixtures of Water, $\mathrm{NaCl}$, and $\mathrm{CO}_{2}$, Lawrence Berkeley National Laboratory, Berkeley, CA, 66 pp., 2005.

Rinaldi, A. P., Vilarrasa, V., Rutqvist, J., and Cappa, F.: Fault reactivation during $\mathrm{CO}_{2}$ sequestration: effects of well orientation on seismicity and leakage, Greenhouse Gases: Science and Technology, 5, 645-656, doi:10.1002/ghg.1511, 2015.

Röhmann, L., Tillner, E., Magri, F., Kühn, M., and Kempka, T.: Fault Reactivation and Ground Surface Uplift Assessment at a Prospective German $\mathrm{CO}_{2}$ Storage Site, Energy Procedia 40, 437446, doi:10.1016/j.egypro.2013.08.050, 2013.

Schlumberger: Petrel Seismic-to-Evaluation Software, Version 2011.2.7, 2011.

Shipton, Z. K. and Cowie, P. A.: A conceptual model for the origin of fault damage zone structures in high-porosity sandstone, J. Struct. Geol., 25, 333-344, doi:10.1016/S0191-8141(02)000378, 2003.

Shipton, Z. K., Soden, A., Kirkpatrick, J., Bright, A., and Lunn, R.: How Thick is a Fault? Fault Displacement-Thickness Scaling Revisited, in: Earthquakes: Radiated Energy and the Physics of Faulting, edited by: Abercrombie, R., McGarr, A., Di Toro, G., and Kanamori, H., American Geophysical Union, Washington DC, 193-198, doi:10.1029/170GM19, 2006.

Span, R. and Wagner, W.: A New Equation of State for Carbon Dioxide Covering the Fluid Region from the Triple-Point Temperature to $1100 \mathrm{~K}$ at Pressures up to $800 \mathrm{MPa}$, J. Phys. Chem. Ref. Data, 25, 1509-1596, doi:10.1063/1.555991, 1996.

Stackebrandt, W.: Grundzüge des geologischen Baus von Brandenburg [Outline of the geological setting of Brandenburg], Brandenburgische Geowissenschaftliche Beiträge, 5, 3-7, 1998.

Stackebrandt, W. and Manhenke, V. (Eds.): Atlas zur Geologie von Brandenburg, 1:1000 000. Landesamt für Geowissenschaften und Rohstoffe Brandenburg (LGRB), 146 pp., 2004.

Tesch, J., Burmann, G., Schwamm, G., and Nillert, P.: Hydrogeologischer Ergebnisbericht mit Grundwasservorratsberechnung, Vorerkundung Fürstenwalde, VEB Hydrogeologie Nordhausen, BT Berlin, 1-309, Berlin, 1987 (unpublished).

Tillner, E., Kempka, T., Nakaten, B., and Kühn, M.: Brine migration through fault zones: 3-D numerical simulations for a prospective 
$\mathrm{CO}_{2}$ storage site in Northeast Germany, Int. J. Greenh. Gas Con., 19, 689-703, doi:10.1016/j.ijggc.2013.03.012, 2013a.

Tillner, E., Kempka, T., Nakaten, B., and Kühn, M.: Geological $\mathrm{CO}_{2}$ Storage Supports Geothermal Energy Exploitation: 3-D Numerical Models Emphasize Feasibility of Synergetic Use, Energy Procedia, 37, 6604-6616, doi:10.1016/j.egypro.2013.06.593, 2013b.

Tillner, E., Shi, J.-Q., Bacci, G., Nielsen, C. M., Frykman, P., Dalhoff, F., and Kempka, T.: Coupled Dynamic Flow and Geomechanical Simulations for an Integrated Assessment of $\mathrm{CO}_{2}$ Storage Impacts in a Saline Aquifer, Energy Procedia, 63, 28792893, doi:10.1016/j.egypro.2014.11.311, 2014.

Trinkwasserverordnung - TrinkwV: Verordnung über die Qualität von Wasser für den menschlichen Gebrauch vom 21.05.2001 (BGB1. I S. 959). Trinkwasserverordnung in der Fassung der Bekanntmachung vom 2. August 2013 (BGBl. I S. 2977), die durch Artikel 4 Absatz 22 des Gesetzes vom 7. August 2013 (BGB1. I S. 3154) geändert worden ist, 2001.

Vattenfall: Antrag auf Erteilung einer Erlaubnis zur Aufsuchung bergfreier Bodenschätze zu gewerblichen Zwecken, http://www.lbgr.brandenburg.de/media_fast/4055/Antrag\%200_ Aufsuchung\%20bergfreier\%20Bodensch\%C3\%A4tze_Bkh_ 20090306.15564291.pdf, 12 pp. (last access: 18 December 2014), 2009.

Vattenfall: Hauptbetriebsplan - Aufsuchungsarbeiten in Bezug auf den bergfreien Bodenschatz Sole im Erlaubnisfeld BirkholzBeeskow, 28 pp., http://www.lbgr.brandenburg.de/media_fast/ 4055/Bkh_HBP_Finale.pdf, (last access: 18 December 2014), 2010.

Vilarrasa, V. and Carrera, J.: Geologic carbon storage is unlikely to trigger large earthquakes and reactivate faults through which $\mathrm{CO}_{2}$ could leak, P. Nat. Acad. Sci. USA, 112, 5938-5943, doi:10.1073/pnas.1413284112, 2015.
Walter, L., Binning, P. J., Oladyshkin, S., Flemisch, B., and Class, H.: Brine migration resulting from $\mathrm{CO}_{2}$ injection into saline aquifers - An approach to risk estimation including various levels of uncertainty, Int. J. Greenh. Gas Con., 9, 495-506, doi:10.1016/j.ijggc.2012.05.004, 2012.

Wibberley, C. A. J., Yielding, G., and Toro, G.: Recent advances in the understanding of fault zone internal structure: a review, in: The Internal Structure of Fault Zones: Implications for Mechanical and Fluid-Flow Properties, edited by: Wibberley, C. A. J., Kurz, W., Imber, J., Holdsworth, R. E., and Collettini, C., Geological Society of London, 5-33, doi:10.1144/SP299.2, 2008.

Yamamoto, H., Zhang, K., Karasakib, K., Marui, A., Hitoshi Uehara, H., and Nishikawa, N.: Numerical investigation concerning the impact of $\mathrm{CO}_{2}$ geologic storage on regional groundwater flow, Int. J. Greenh. Gas Con., 3, 586-599, doi:10.1016/j.ijggc.2009.04.007, 2009.

Zeidouni, M.: Analytical model of leakage through fault to overlying formations, Water Resour. Res., 48, W00N02, doi:10.1029/2012WR012582, 2012.

Zhang, K., Wu, Y. S., and Pruess, K.: User's Guide for TOUGH2MP - A Massively Parallel Version of the TOUGH2 Code, Earth Sciences Division, Lawrence Berkeley National Laboratory, Berkeley, 108 pp., 2008.

Zhou, Q., Birkholzer, J., Mehnert, E., Lin, Y., and Zhang, K.: Modelling Basin- and Plume-Scale Processes of $\mathrm{CO}_{2}$ Storage for Full-Scale Deployment, Ground Water, 48, 494-514, doi:10.1111/j.1745-6584.2009.00657.x, 2010. 